\title{
Geo(Im)pulse
}

\section{An investigation into the genesis of an erratic (retro) eclogite block from Haren, Groningen, the Netherlands}

\section{J. Langendoen ${ }^{1,2, *}$ \& H.L.M. van Roermund ${ }^{2}$}

1 Bereklauw 1, 2761 WZ Naaldwijk, the Netherlands.

2 Structural Geology Group, Institute of Earth Sciences, Utrecht University, P.0. Box 80021, 3508 TA Utrecht, the Netherlands.

* Corresponding author. Email: janfran@xs4all.nl

Manuscript received: July 2006; accepted: June 2007

\begin{abstract}
In boulder clays and glacial deposit sands, exposed in the northern part of the Netherlands, erratic blocks of (ultra)high pressure (UHP) metamorphic rocks may be found that originate from the Baltic Shield (Scandinavia). The occurrence of (U)HP metamorphic rocks in Scandinavia is limited to: (1) isolated occurrences within the Scandinavian Caledonides (Western part of Scandinavia); (2) Sveconorvegian rocks from the Halland area, Southwest Sweden; and (3) Kola Peninsula (Northern Scandinavia). For this reason (U)HP rocks form excellent indicator pebbles/rocks that may be used to trace back the source area from where the erratic blocks, found in the Netherlands, were derived. An example of this, an erratic (retro) eclogite block found in Haren, is investigated in the present study using naked eye, light-optical and electron microprobe (EMP) techniques. EMP mineral analyses were used to reconstruct the PT conditions under which the (retro) eclogite was formed $\left(\mathrm{T}=756^{\circ} \mathrm{C} / \mathrm{min} . \mathrm{P}=16,2 \mathrm{~kb}\right.$ ). This result, in combination with the mineral chemistry of the major rock forming minerals, provides evidence that this erratic block originates from the upper HP tectonic lens exposed in the Caledonian Seve Nappe Complex of Northern Jämtland, Sweden.
\end{abstract}

Keywords: indicator rock, glaciation, (U)HPM rocks, Scandinavia.

\section{Introduction}

In the last 50 years a few erratic eclogite blocks were found in the Netherlands. G. Dijk from Groningen discovered one of them. In 1965, he found during digging activities, at the corner of the Rijksstraatweg and the Potgieterlaan in Haren (Gr.), an (retro) eclogite (Fig.1) at a depth level of approx. $2 \mathrm{~m}$ (pers. comm.).

Haren is situated about $6 \mathrm{~km}$ south-south-east of the city Groningen and is lying on a hill range with a length of $70 \mathrm{~km}$ existing of glacial deposit sand and boulder clay, called the Hondsrug (Fig. 2). The boulder clay is from Saalian age and includes erratic blocks.

According to Huisman (1982), curator of the Natuurmuseum Groningen, this (retro) eclogite originated from Scandinavia. For more information on erratic blocks from Scandinavia found in the Netherlands, Denmark and Germany, the reader is referred to Zandstra (1988 and 1999) and Smed (1994).
This article describes the results of a detailed light optical and electron microprobe (EMP) study of this erratic (retro) eclogite block. We have made EMP analyses of the major rock

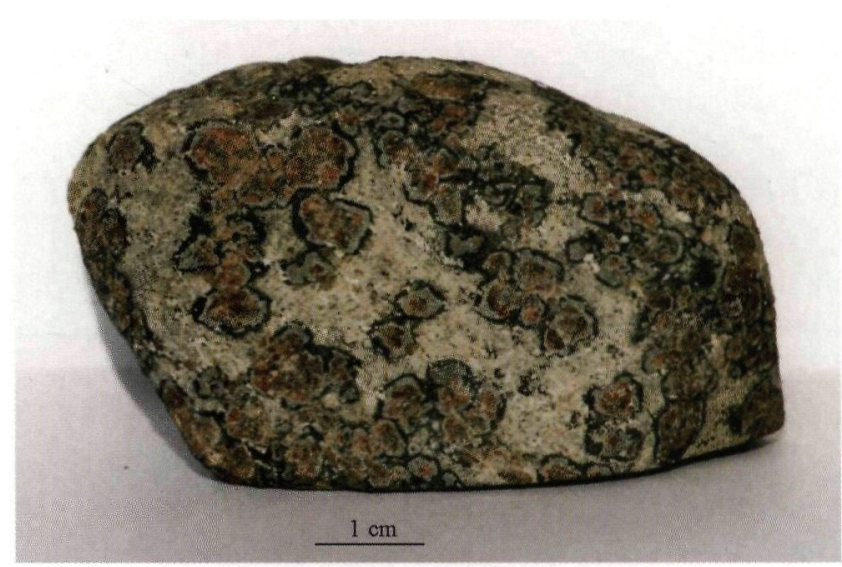

Fig. 1. Erratic (retro) eclogite block from Haren, Groningen. 
forming minerals to reconstruct the PT conditions of eclogite formation. These results were used to make a comparative study with similar literature data, described from various (U)HP metamorphic terranes spread out over the Baltic Shield, allowing the source area of this erratic (retro) eclogite block to be determined.

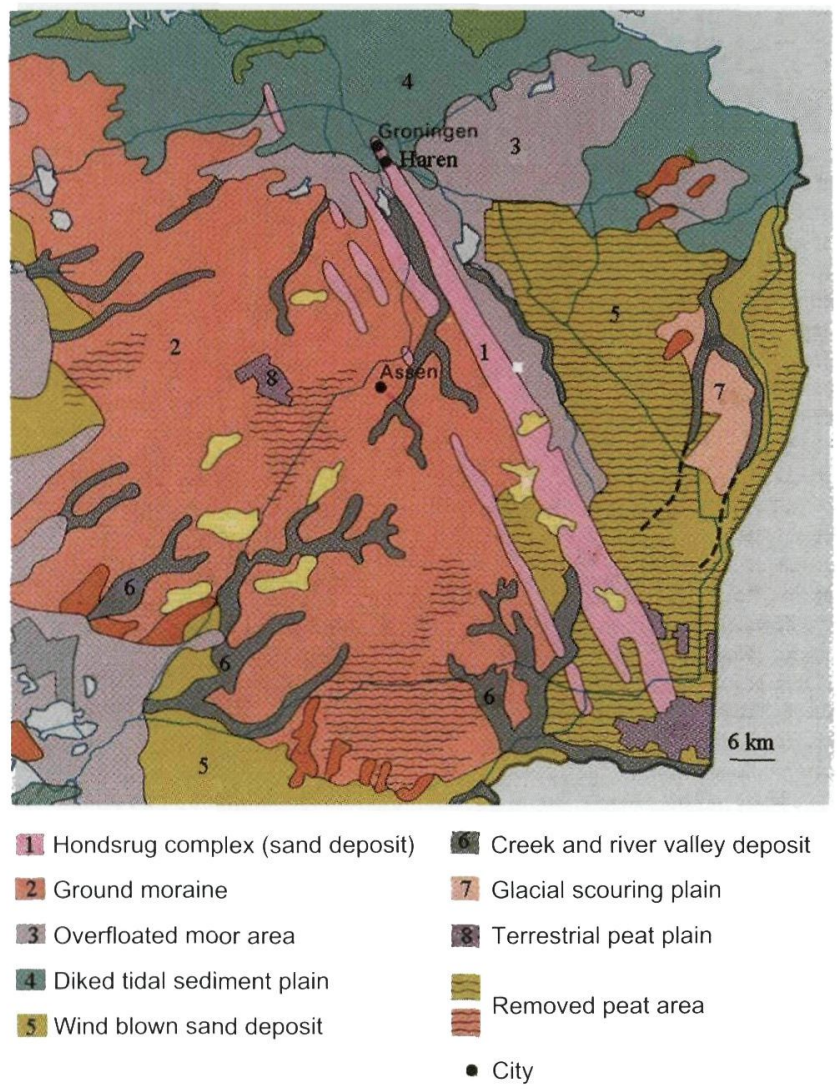

Fig. 2. Geological map of the Hondsrugcomplex. The (retro) eclogite block was found in Haren at a depth level of approx. $2 \mathrm{~m}$. Modified after Stichting Wetenschappelijke Atlas van Nederland (1985)

\section{Method}

Mineral-major element compositions were determined by EMP analyses at Utrecht University using a JEOL JXA-8600 superprobe. Operating conditions: $15 \mathrm{kV}, 20 \mathrm{nA}, 30 \mathrm{~s}$ counting time in wavelength dispersive spectrometry mode, ZAF routine and external calibrations against international silicate standards.

\section{(U)HP metamorphic terranes in Scandinavia (Fig. 3)}

By definition an eclogite is an (ultra) high pressure (UHP) metamorphic (M) rock that consists of garnet and sodium bearing clinopyroxene (omphacite) in the absence of plagioclase (Carswell 1990).

Eclogite is an important rock type of (U)HPM terranes, formed during orogeny when two plates collide with each other. (U)HPM terranes are simply exhumed fossil subduction zones that represent those parts of the colliding plates that

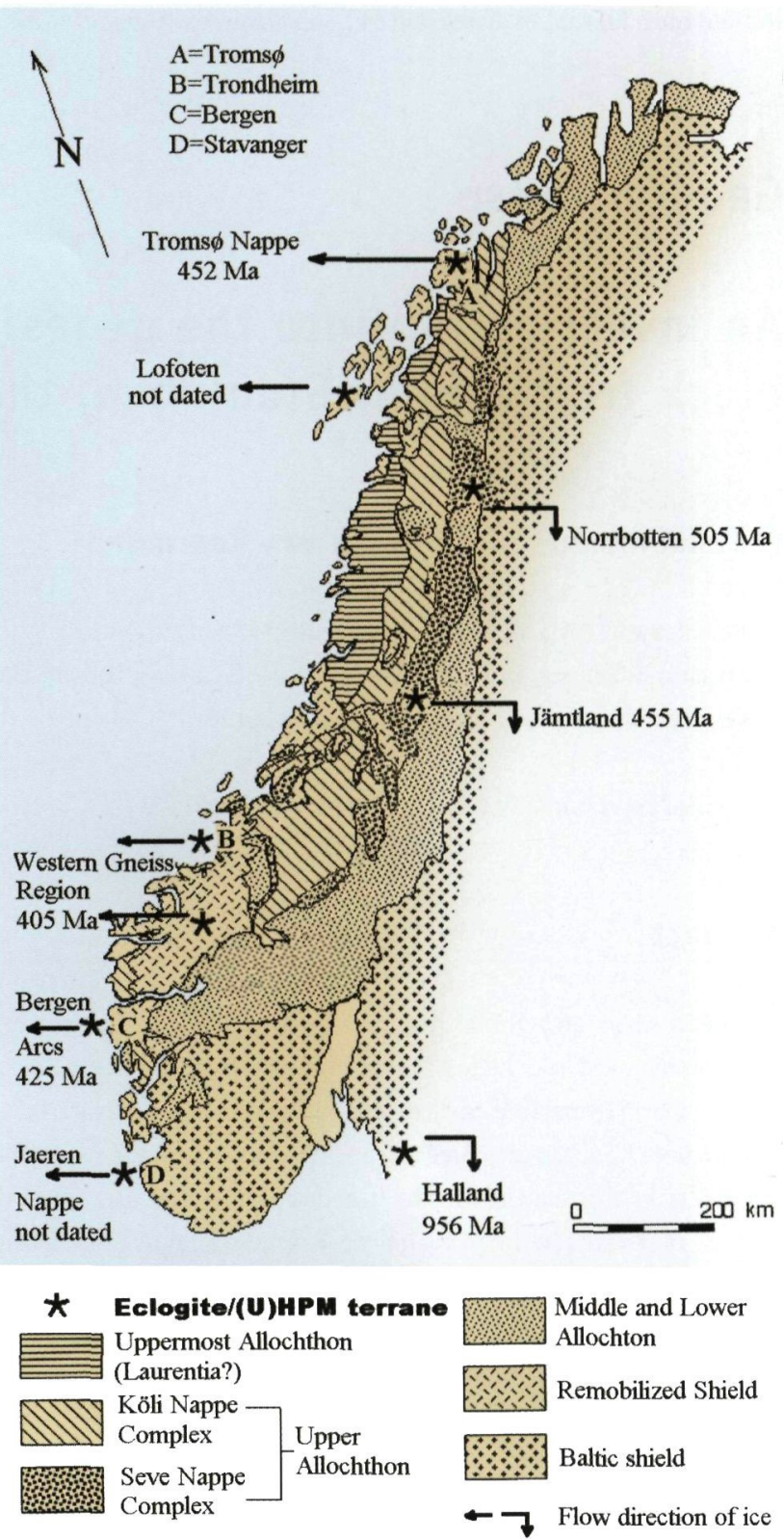

Fig. 3. Terrane map of the Scandinavian Caledonides (Western part of the Baltic Shield). The Scandinavian Caledonides are subdivided into four Allochthons (Nappe Complexes) lying on top of the Baltic Shield. With the star symbol the occurrences of eclogite bearing (U)HPM terranes are indicated. Modified after Brueckner and Van Roermund (2004).

once became subducted below and/or underneath the overriding plate. This subducting plate geometry creates the relatively cold geodynamic environment that is required for the growth of (U)HPM minerals (Carswell 1990).

Exposed (U)HPM terranes on the Baltic Shield are relatively scarce (Fig. 3). Most of them are related to the formation of the Scandinavian Caledonides, a mountain belt that was formed 500-380 Ma ago when the two adjacent continents, Baltica and Laurentia, collided with each other after consumption of the Iapetus Ocean that lied in between these two continents (Brueckner \& Van Roermund 2004). 
The locations of exposed Caledonian and/or Sveconorvegian (U)HPM terranes within the Scandinavian Caledonides are indicated with a star symbol (eclogite/(U)HPM terranes) in Fig. 3. Recently two other (U)HPM terranes were discovered in the northern part of the Baltic Shield: the Salma area, Kola Peninsula and the Gridino area, Northern Karelia (Kaulina and Apanasevich 2005). These locations are not mentioned in Fig. 3. The reason for it will be discussed below.

\section{Potential source areas for erratic (U)HPM blocks}

Taking into account the flow directions of the ice during glacial times only locations Halland, Northern Jämtland and Norrbotten can be considered as potential source areas for erratic (U)HPM blocks found in the Netherlands. All other (U)HPM terranes indicated in Fig. 3 can safely be excluded, included the two terranes in the northern part of the Baltic Shield. The ice in the western part of Scandinavia floated westwards into the Atlantic 0cean and the ice in the northern part floated northwards into the Barentsz Sea, consequently the ice from these places never reached the Netherlands. For this reason these terranes were excluded in the present study. The flow directions of the ice are indicated in Fig. 3 by black arrows. Below a summary of the three remaining (U)HPM terranes is given.

\section{The eclogite-bearing terrane in Halland, Southwest Sweden}

The eclogites from Halland (Fig. 3) were formed during the Sveconorvegian (Grenvillian) Orogeny around $950 \mathrm{Ma}$ ago. For a review of the geodynamic setting the reader is referred to Bingen et al., (2005) and Berglund \& Connelly (1994). The terrane in Halland has roughly $\mathrm{N}-\mathrm{S}$ trending metamorphic belts of Svecokarelian (1850-1650 Ma), Svecofennian (1890-1750 Ma) and Sveconorvegian (1200 - $950 \mathrm{Ma}$ ) age. The Sveconorvegian Belt in the west consists of an Eastern and Western Segment separated by a mylonite zone. In the Southern part of the Eastern Segment, eclogites were found near Ullared (Möller 1998 and Möller 1999). All these eclogites are strongly retrogressed, including widespread plagioclase formation.

Consequently only retrograde PT conditions were determined $\mathrm{T}=750 \pm 45^{\circ} \mathrm{C}$ and $\mathrm{P} \geqslant 10.8 \pm 1.2 \mathrm{~kb}$ (Möller 1998). (U)HPM was dated as $956 \pm 7$ Ma years old (Möller and Söderlund 1997). In addition to garnet, clinopyroxene and plagioclase, the retrograde eclogites contain kyanite with sapphirine-plagioclase coronas.

\section{The eclogite bearing terranes in Northern Jämtland, Central Sweden}

In Northern Jämtland eclogites occur in the Seve Nappe Complex representing the lower part of the Upper Allochthon (Fig. 3) and interpreted to be the continent-ocean transition zone between Baltica and the ocean that opened outboard of it.
In Northern Jämtland/Southern Västerbotten, the Seve Nappe Complex is traditionally divided from top to bottom into a Western, Central and Eastern Belt (Zwart, 1974; Williams and Zwart 1977). However towards the south (Northern Jämtland) the Western Belt is absent. Here Van Roermund $(1985 ; 1989)$ and Van Roermund \& Bakker (1984) recognised eclogite bearing tectonic lenses in the two remaining Belts: the Ertsekey Lens in the Central Belt and the Tjeliken Lens in the Eastern Belt. The Tjeliken eclogites are largely metamorphosed dikes and intrusives associated with unmigmatized quartzofeldspathic gneiss with minor intercalations of garnet-mica schist, amphibolite, marble and garnet peridotite.

The Ertsekey eclogites are associated with migmatitic kyanite/sillimanite potash-feldspar gneiss. Minor intercalations of quartzite, garnet-mica schist, amphibolite, marble and (garnet) peridotite occur. In addition the primary mineral assemblage of the eclogites is (Van Roermund 1985):

- Central Belt: omphacite + garnet + quartz + rutile + zircon + apatite + zoisite;

- Eastern Belt: omphacite + garnet + quartz + rutile + zircon + apatite + phengite

The following PT conditions for eclogite formation were determined by Van Roermund (1985):

- Central Belt eclogites $\mathrm{P} \geqslant 18,0 \pm 1,0 \mathrm{~kb}$ and $\mathrm{T}=780 \pm 50^{\circ} \mathrm{C}$;

- Eastern Belt eclogites $\mathrm{P} \geqslant 14,0 \pm 1,5 \mathrm{~kb}$ and $\mathrm{T}=550 \pm 70^{\circ} \mathrm{C}$, but these PT conditions were recently updated to $\mathrm{T}=650$ $\pm 50^{\circ} \mathrm{C}$ and $\mathrm{P} \geqslant 16,5 \pm 1 \mathrm{~kb}$ (Litjens, 2002)

The age, determined by Sm-Nd techniques, of (U)HPM in the Central and Eastern Belt is $455 \mathrm{Ma}$ (Brueckner \& Van Roermund, 2004; 2006) suggesting both Nappes were subducted/educted simultaneously.

\section{The eclogite bearing terranes in Norrbotten, North Sweden}

The Seve Nappe Complex can be followed in northern direction (Fig. 3) from Northern Jämtland through Västerbotten to Norrbotten (Stephens \& Van Roermund, 1984). In Norrbotten two eclogite bearing terranes were recognised: in the north the Råvvejaure area, in the south the Grapesvare area. In the Råvvejaure area the Seve Nappe is subdivided into two lenses, Sarek Lens and Tsäkkok Lens (Kullerud, Stephens and Zachrisson, 1990). The Tsäkkok Lens contains eclogites. In the Grapesvare area (Andreasson, Gee and Sukotji, 1985; Albrecht, 2000) the Seve Nappe is subdivided into three nappes, Lower Seve Nappe, Grapesvare Nappe and Maddåive Nappe (the three together were formerly called Vaimok Lens). Eclogites occur only in the Grapesvare- and Maddåive Nappe. In the Råvvejaure and Grapesvare area the lenses/nappes are correlated with the thinned margin of Baltica and the rift-related sediments deposited on this margin (Albrecht, 2000). 
The primary mineral assemblage of the Vaimok eclogites is garnet, omphacite, rutile, quartz \pm phengite (Santallier 1988), the Tsäkkok eclogites contain zoisite in addition (Mørk, Kullerud and Stabel, 1988). Estimated PT conditions for eclogites in the Tsäkkok Lens are: $\mathrm{P} \geqslant 14,9 \pm 1,5 \mathrm{~kb}$ and $\mathrm{T}=610 \pm 90{ }^{\circ} \mathrm{C}$ (Stephens and Van Roermund, 1984). For the Vaimok eclogites: $\mathrm{P} \geqslant 19 \pm 1 \mathrm{~kb}$ and $\mathrm{T}=700 \pm 50{ }^{\circ} \mathrm{C}$ (Santallier, 1988; Mørk, Kullerud and Stabel, 1988).

The age determined by the Sm-Nd method is $505 \pm 18 \mathrm{Ma}$. This suggests that the two nappes subducted at the same time (Mørk, Kullerud and Stabel, 1988). The age is corroborated by $\mathrm{U}-\mathrm{Pb}$ ages from titanites in associated rocks (Essex, Gromet, Andreasson and Albrecht, 1997).

\section{Results}

A polished thin section and a scanned image were made of the erratic (retro) eclogite block (Fig. 4). Also indicated in Fig. 4 are the areas that were investigated by EMP analyses. The

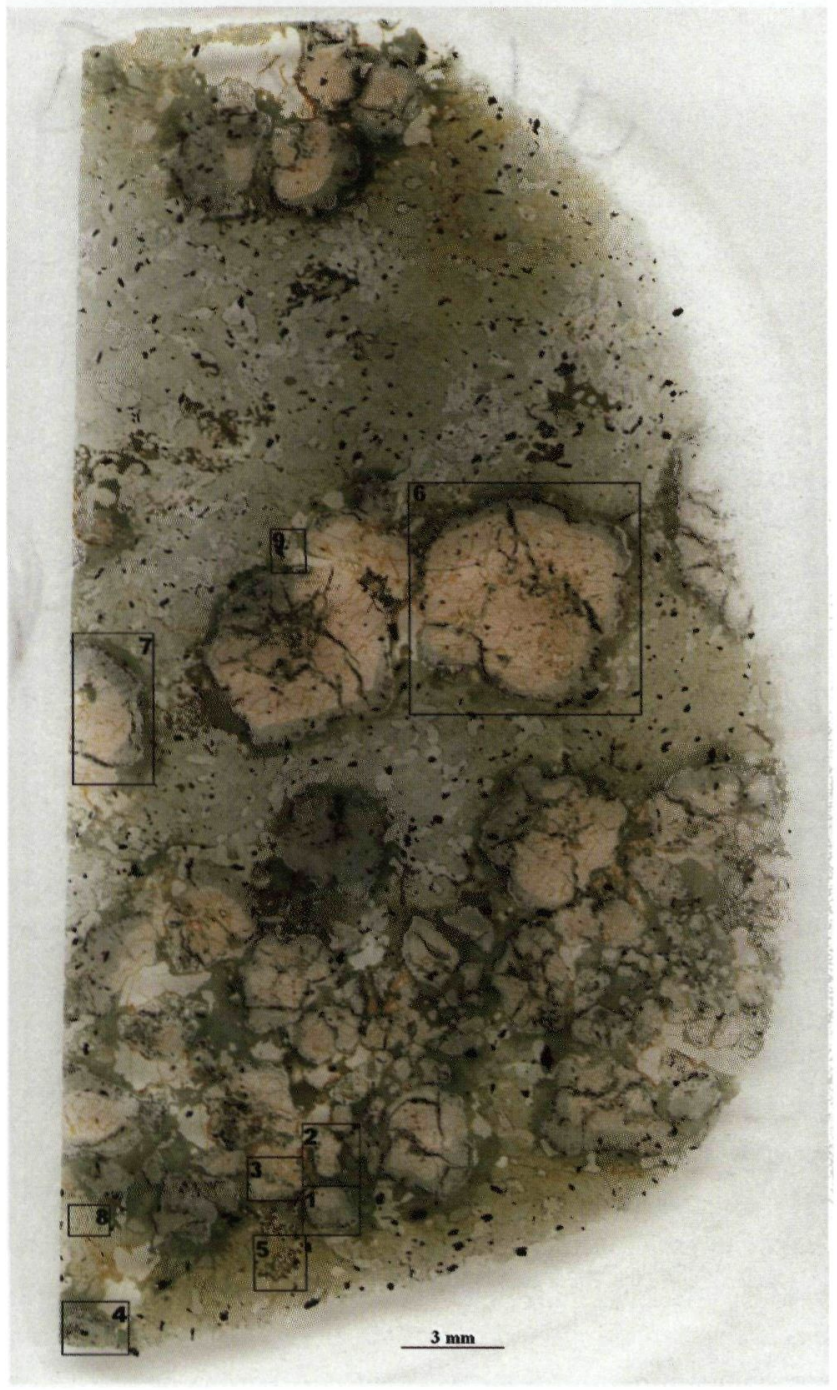

Fig. 4. Scanned micrograph of polished thin section from the studied erratic (retro) eclogite block. Outlines refer to investigated areas studied with EMP. mineralogy of the Haren (retro) eclogite boulder consists of garnet-diopsidic clinopyroxene-orthopyroxene-amphiboleplagioclase-quartz-epidote group minerals-opaque.

The Haren eclogite is heavily retrogressed (Fig. 1 and 4) and basically the rock should not be called an eclogite but a retro-eclogite. This is clearly illustrated by:

1. the kelyphitic rims around garnet (Fig. 1 and 5a) that consist of intergrowths between calcic amphibole (magnesiohastingsite) and plagioclase. The composition of plagioclase varies from bytownite close to the garnet, to labradorite in the middle, to andesine at the contact with the matrix. In addition, along the outer rim opaques are present (Fig. 8b);

2. the omphacitic matrix of the Haren (retro) eclogite is fully transformed into a symplectitic intergrowth of clinopyroxeneplagioclase (Fig. 6b).

No primary omphacite crystals were found in the matrix. Omphacite occurs only as isolated but subordinate inclusions in garnet (Fig. 6a). Isolated quartz grains in symplectite are always surrounded by clinopyroxene coronas. There are also quartz grains found as inclusions in garnet that are surrounded by othopyroxene-plagioclase coronas that are later partly replaced by amphibole (mostly magnesio-hornblende) and plagioclase (andesine, Fig.7).

Representive EPM mineral analyses of garnet, pyroxene, amphibole and plagioclase are given in Tables 1 - 5, compositional end-member diagrams of garnet, clinopyroxene, amphibole and plagioclase are given in Fig. 5b, Fig. 6c, Fig. 8c - e and Fig. 9b.

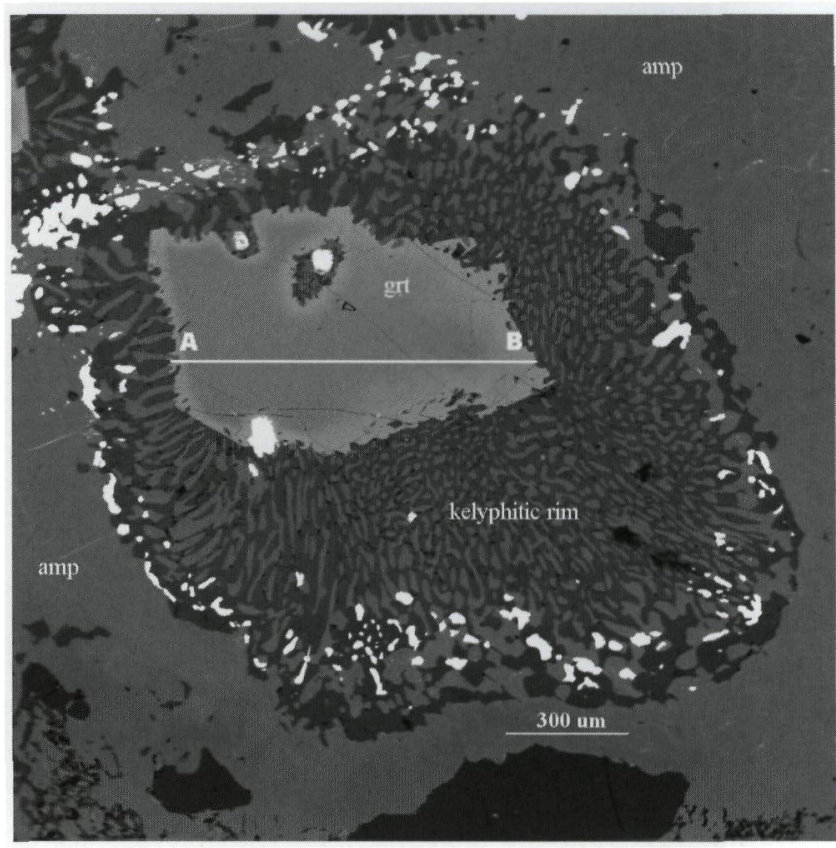

Fig. 5a. Backscattered electron micrograph illustrating a kelyphitic rim around garnet, embedded in symplectitic matrix; dark = plagioclase, white $=$ opaque and grey $=$ amphibole. Location: square 1 in Fig. 4. 


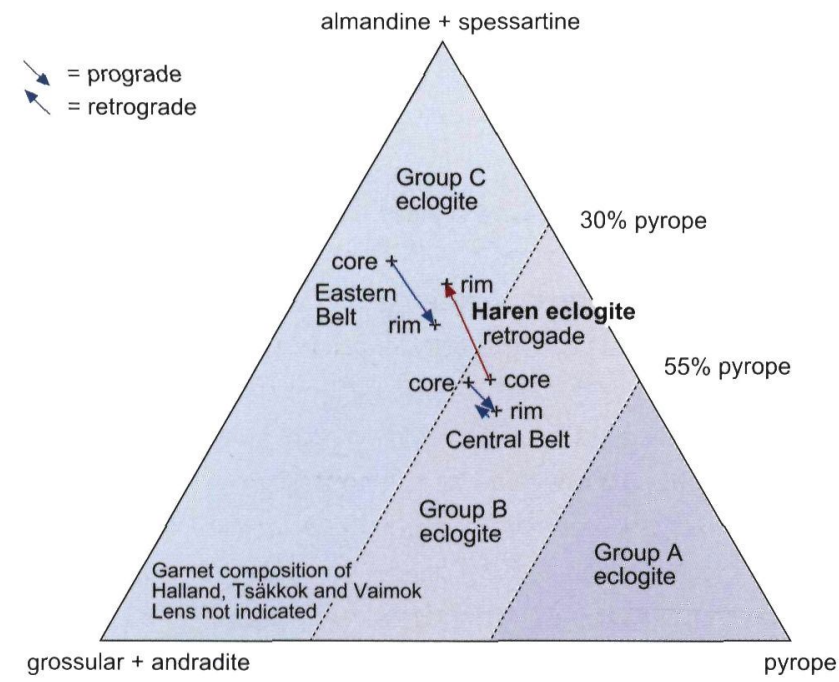

Fig. 5b. Triangular end-member diagram of garnet compositions (analysis number 2y11, Fig. 5a). The change in garnet composition from core to rim is indicated by an arrow. Also indicated is the position of the Haren eclogitic garnet composition (red arrow) with respect to garnet composition from the eclogites of Eastern Belt and Central Belt (blue arrows). Location: square 1 in Fig. 4.

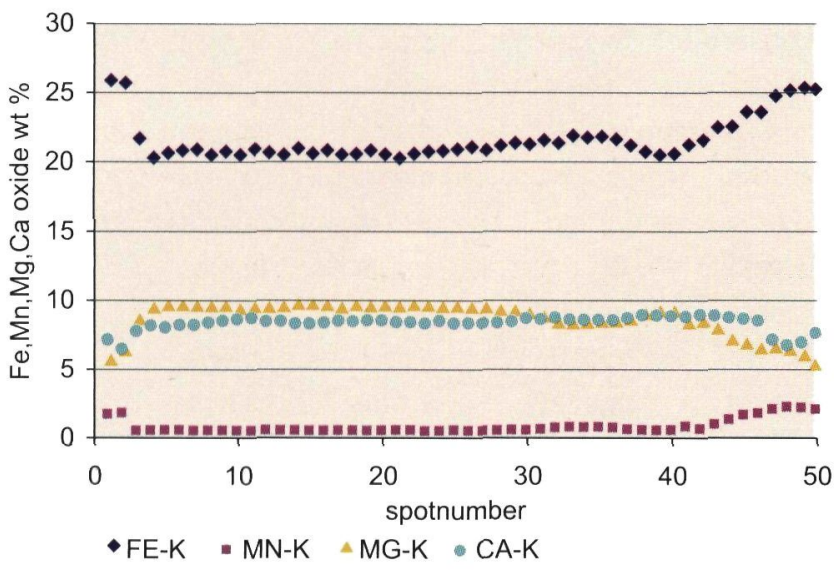

Fig. 5c. Microprobe step scan profile across garnet (analysis number 2y11). The trace $A-B$ is indicated in Fig. 5a. Fe and $M n$ increase near the rim and $\mathrm{Mg}$ and $\mathrm{Ca}$ decrease.

\section{Garnet}

Representative EMP garnet analyses, a triangular end-member diagram and an EMP step scan profile across garnet (analysis number 2y11) are given in Table 1, Fig. 5b and Fig. 5c. Coleman, Lee, Beatty and Brannock (1965) divided the composition of eclogitic garnets into three groups. Group A: inclusions in kimberlites, basalts, or layers in ultramafic rocks; group B: bands or lenses within migmatitic gneiss terranes and group $\mathrm{C}$ : bands or lenses within alpine-type metamorphic rocks. These groups are indicated in Fig. 5b. Also indicated in Fig. 5b is the garnet mineral chemistry of the Haren (retro) eclogite and for comparative reasons garnets from the Eastern and the Central Belt of the Seve Nappe Complex in Northern Jämtland.
Table 1. Representative EMP analyses and calculated structural formulae from rim and core of garnet analysis number $2 y 11$, based on 12 oxygen. Fe $e^{3+}$ is calculated following Schumacher (1997). Location: square 1 in Fig. 4.

\begin{tabular}{lccc}
\hline Analysis & $\begin{array}{c}\text { Rim, spot- } \\
\text { number } 1\end{array}$ & $\begin{array}{c}\text { Core, spot- } \\
\text { number 25 }\end{array}$ & $\begin{array}{c}\text { Rim, spot- } \\
\text { number 50 }\end{array}$ \\
\hline $\mathrm{SiO}_{2}$ & 38.529 & 39.332 & 38.248 \\
$\mathrm{TiO}_{2}$ & 0.020 & 0.042 & 0.002 \\
$\mathrm{Al}_{2} \mathrm{O}_{3}$ & 21.414 & 21.747 & 21.261 \\
$\mathrm{Cr}_{2} \mathrm{O}_{3}$ & 0.000 & 0.039 & 0.000 \\
$\mathrm{FeO}$ & 25.566 & 20.614 & 25.119 \\
$\mathrm{MnO}$ & 1.664 & 0.515 & 2.036 \\
$\mathrm{MgO}$ & 5.406 & 9.303 & 5.216 \\
$\mathrm{CaO}$ & 7.124 & 8.323 & 7.631 \\
$\mathrm{Na}_{2} \mathrm{O}$ & 0.000 & 0.017 & 0.007 \\
\hline $\mathrm{Total}$ & 99.724 & 99.933 & 99.520
\end{tabular}

\begin{tabular}{lccc}
\hline Element & No. of cations & No. of cations & No. of cations \\
\hline $\mathrm{Si}$ & 3.0315 & 2.9929 & 3.0043 \\
$\mathrm{Ti}$ & 0.0012 & 0.0024 & 0.0001 \\
$\mathrm{Al}$ & 1.9740 & 1.9504 & 1.9682 \\
$\mathrm{Cr}$ & 0.0000 & 0.0024 & 0.0000 \\
$\mathrm{Fe}$ & 1.6722 & 1.3118 & 1.6500 \\
$\mathrm{Mn}$ & 0.1102 & 0.0332 & 0.1355 \\
$\mathrm{Mg}$ & 0.6303 & 1.0553 & 0.6108 \\
$\mathrm{Ca}$ & 0.5970 & 0.6786 & 0.6422 \\
$\mathrm{Na}$ & 0.0000 & 0.0025 & 0.0011 \\
$\mathrm{Total}$ & 7.9984 & 8.0295 & 8.0120 \\
\hline & & & \\
$\mathrm{Fe}^{3+}$ & 0.0000 & 0.0880 & 0.036 \\
$\mathrm{Fe}^{2+}$ & 1.6722 & 1.2180 & 1.611 \\
\hline
\end{tabular}

The step scan profile (Fig. $5 \mathrm{c}$ ) reveals that the Haren eclogitic garnet is chemically zoned. This is also clearly visible in Fig. $5 \mathrm{a}$ showing a change in grey-shading of the garnet towards the edge of the grain. Garnet cores are relatively homogeneous in composition with contents of around 42\% almandine, 35\% pyrope and 23\% grossular. Towards the garnet rim Fe and Mn increase while $\mathrm{Mg}$ and Ca decrease, resulting in approx. 58\% almandine, $21 \%$ pyrope and $21 \%$ grossular. This mineral-chemical change in garnet composition is indicated by an arrow in the triangular end-member diagram of Fig. $5 \mathrm{~b}$ and interpreted to be due to decompression postdating eclogite formation.

\section{Clinopyroxene}

Representative EMP clinopyroxene analyses and a triangular end-member diagram are given in Table 2 and Fig. 6c. Two types of clinopyroxenes were recognised. The first one occurs as inclusions in garnet (Fig. 6a), its composition corresponds to that of omphacite containing a jadeite component of 32.6 $33.1 \%$ (Fig. 6c). The second type is found in polycrystalline 
Table 2. Representative EMP analyses and calculated structural formulae of clinopyroxene type 1 included in garnet, location: square 2 in Fig. $4 ;$ type 2 within pyroxene-plagioclase symplectite (or in polycrystalline coronas around quartz grains), location: square 8 in Fig. 4 . All analyses based on 6 oxygen, $\mathrm{Fe}^{3+}$ is calculated following Schumacher (1997).

\begin{tabular}{|c|c|c|c|c|c|c|c|c|c|}
\hline \multirow{2}{*}{$\begin{array}{l}\text { Analysis } \\
\text { number }\end{array}$} & \multicolumn{2}{|c|}{ Inclusion in grt } & \multicolumn{3}{|c|}{ In symplectite intermediary } & \multicolumn{2}{|c|}{ In symplectite coarse } & \multicolumn{2}{|c|}{ In symplectite fine } \\
\hline & $2 \mathrm{y} 12 \mathrm{a}$ & $2 \mathrm{y} 12 \mathrm{~d}$ & $2 \mathrm{y} 16-1 \mathrm{~g}$ & $2 \mathrm{y} 16-1 \mathrm{i}$ & $2 \mathrm{y} 16-1 \mathrm{~m}$ & $2 \mathrm{y} 16-1 \mathrm{~s}$ & $2 y 16-1 u$ & $2 \mathrm{y} 16-3 a$ & $2 y 16-3 i$ \\
\hline $\mathrm{SiO}_{2}$ & 52.797 & 52.852 & 52.464 & 52.567 & 50.953 & 52.337 & 52.975 & 53.334 & 53.900 \\
\hline $\mathrm{TiO}_{2}$ & 0.106 & 0.401 & 0.427 & 0.183 & 0.747 & 0.282 & 0.098 & 0.082 & 0.129 \\
\hline $\mathrm{Al}_{2} \mathrm{O}_{3}$ & 8.604 & 8.687 & 2.801 & 1.939 & 3.835 & 2.395 & 1.935 & 1.493 & 1.644 \\
\hline $\mathrm{Cr}_{2} \mathrm{O}_{3}$ & 0.106 & 0.216 & 0.059 & 0.209 & 0.137 & 0.032 & 0.153 & 0.069 & 0.157 \\
\hline $\mathrm{FeO}$ & 7.231 & 7.284 & 8.237 & 7.891 & 8.517 & 7.957 & 7.967 & 7.620 & 7.354 \\
\hline $\mathrm{MnO}$ & 0.000 & 0.048 & 0.257 & 0.326 & 0.155 & 0.172 & 0.227 & 0.076 & 0.214 \\
\hline $\mathrm{MgO}$ & 9.357 & 9.198 & 12.519 & 13.220 & 12.028 & 13.030 & 13.358 & 13.621 & 13.887 \\
\hline $\mathrm{CaO}$ & 16.456 & 16.033 & 22.574 & 22.863 & 22.488 & 22.828 & 22.689 & 22.966 & 22.977 \\
\hline $\mathrm{Na}_{2} \mathrm{O}$ & 4.392 & 4.373 & 0.895 & 0.928 & 1.074 & 0.918 & 0.834 & 0.800 & 0.743 \\
\hline $\mathrm{K}_{2} \mathrm{O}$ & 0.006 & 0.000 & 0.052 & 0.017 & 0.063 & 0.034 & 0.000 & 0.016 & 0.072 \\
\hline Total & 99.055 & 99.091 & 100.29 & 100.14 & 99.998 & 99.986 & 100.24 & 100.08 & 101.08 \\
\hline Element & & & & No. of cat & ns & & & & \\
\hline $\mathrm{Si}$ & 1.9437 & 1.9433 & 1.9472 & 1.9581 & 1.9053 & 1.9509 & 1.9645 & 1.9796 & 1.9779 \\
\hline $\mathrm{Ti}$ & 0.0029 & 0.0111 & 0.0119 & 0.0051 & 0.0210 & 0.0079 & 0.0027 & 0.0023 & 0.0036 \\
\hline $\mathrm{Al}$ & 0.3733 & 0.3764 & 0.1225 & 0.0851 & 0.1690 & 0.1052 & 0.0846 & 0.0653 & 0.0711 \\
\hline $\mathrm{Cr}$ & 0.0031 & 0.0063 & 0.0017 & 0.0062 & 0.0041 & 0.0009 & 0.0045 & 0.0020 & 0.0046 \\
\hline $\mathrm{Fe}$ & 0.2226 & 0.2240 & 0.2557 & 0.2458 & 0.2664 & 0.2481 & 0.2471 & 0.2365 & 0.2257 \\
\hline $\mathrm{Mn}$ & 0.0000 & 0.0015 & 0.0081 & 0.0103 & 0.0049 & 0.0054 & 0.0071 & 0.0024 & 0.0066 \\
\hline $\mathrm{Mg}$ & 0.5135 & 0.5042 & 0.6927 & 0.7341 & 0.6705 & 0.7241 & 0.7385 & 0.7537 & 0.7597 \\
\hline $\mathrm{Ca}$ & 0.6491 & 0.6316 & 0.8977 & 0.9125 & 0.9010 & 0.9117 & 0.9015 & 0.9133 & 0.9034 \\
\hline $\mathrm{Na}$ & 0.3135 & 0.3118 & 0.0644 & 0.0670 & 0.0779 & 0.0663 & 0.0599 & 0.0576 & 0.0528 \\
\hline $\mathrm{K}$ & 0.0003 & 0.0000 & 0.0025 & 0.0008 & 0.0030 & 0.0016 & 0.0000 & 0.0008 & 0.0034 \\
\hline Total & 4.0220 & 4.0101 & 4.0044 & 4.0250 & 4.0231 & 4.0221 & 4.0104 & 4.0136 & 4.0088 \\
\hline $\mathrm{Fe}^{3+}$ & 0.061 & 0.030 & 0.028 & 0.074 & 0.077 & 0.064 & 0.046 & 0.040 & 0.027 \\
\hline $\mathrm{Fe}^{2+}$ & 0.160 & 0.193 & 0.228 & 0.170 & 0.187 & 0.182 & 0.200 & 0.196 & 0.198 \\
\hline Jd & $32.6 \%$ & $33.1 \%$ & $6.7 \%$ & $4.4 \%$ & $7.6 \%$ & $5.7 \%$ & $5.1 \%$ & $4.6 \%$ & $5.1 \%$ \\
\hline $\mathrm{Di}$ & $53.3 \%$ & $53.4 \%$ & $72.0 \%$ & $74.9 \%$ & $68.7 \%$ & $74.0 \%$ & $76.8 \%$ & $77.6 \%$ & $79.4 \%$ \\
\hline Hd & $14.1 \%$ & $13.5 \%$ & $21.3 \%$ & $18.2 \%$ & $23.6 \%$ & $19.2 \%$ & $17.0 \%$ & $16.4 \%$ & $15.0 \%$ \\
\hline $\mathrm{Ae}$ & $0.0 \%$ & $0.0 \%$ & $0.0 \%$ & $2.5 \%$ & $0.1 \%$ & $1.1 \%$ & $1.1 \%$ & $1.4 \%$ & $0.5 \%$ \\
\hline
\end{tabular}

coronas around larger quartz grains embedded in symplectite or in pyroxene-plagioclase symplectites (Fig. 6b). It corresponds to a diopsidic clinopyroxene (sodic augite), see Fig. 6c, containing a jadeite component $\leqslant 8$.

\section{Orthopyroxene}

Orthopyroxene was found together with plagioclase as coronas around quartz grains (Fig. 7). Representative EMP orthopyroxene analyses are given in Table 3. 0rthopyroxene contains $63.0-64.3 \%$ enstatite and $35.7-37.0 \%$ ferro-silite components (Table 3).

\section{Amphibole}

Representative EMP amphibole analyses are given in Table 4; amphibole classification diagrams (Leake et al. 1997) are presented in Fig. 8c, 8d and 8e.

Four types of amphiboles were recognised:

- Type 1 occurs as inclusion in garnet (Fig. 6a and 8a). Different compositions of calcic amphiboles (Fig. 6a) were analysed that correspond to magnesio-hastingsite, analysis number 2y12f (Fig. 8e) and magnesio-hornblende, analysis number $2 \mathrm{y} 12 \mathrm{~b}$ (Fig. 8d). The optical colour of the amphibole is green or greyish green. Another amphibole included in 


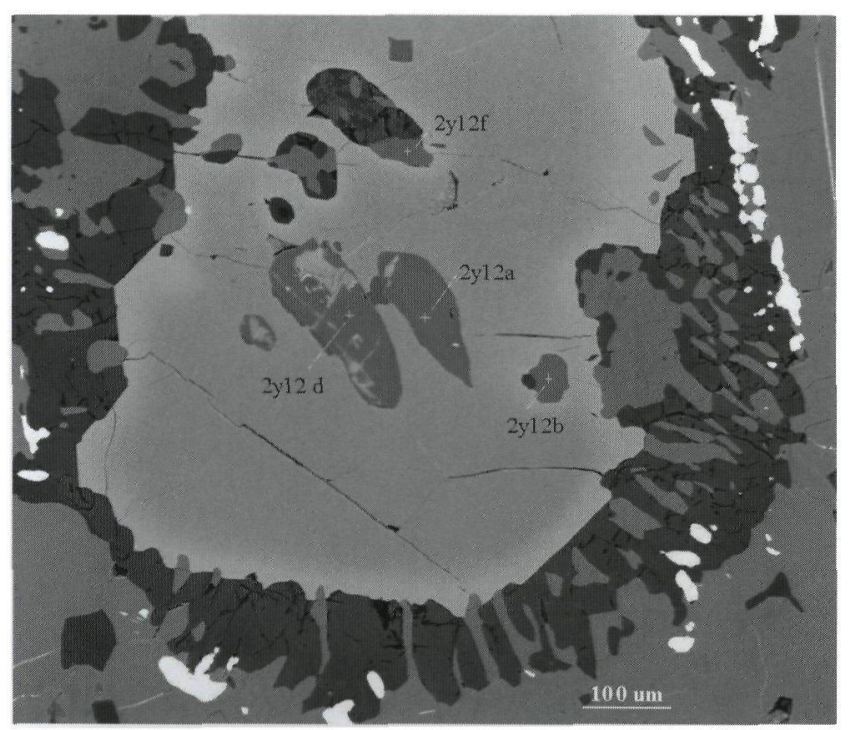

Fig. 6a. Backscattered electron micrograph illustrating type 1 clinopyroxene inclusions in garnet (analyses numbers $2 y 12 a$ and $2 y 12 d$ ). Analyes numbers $2 y 12 b$ and $2 y 12 f$ are amphiboles (type 1). Location: square 2 in Fig. 4.

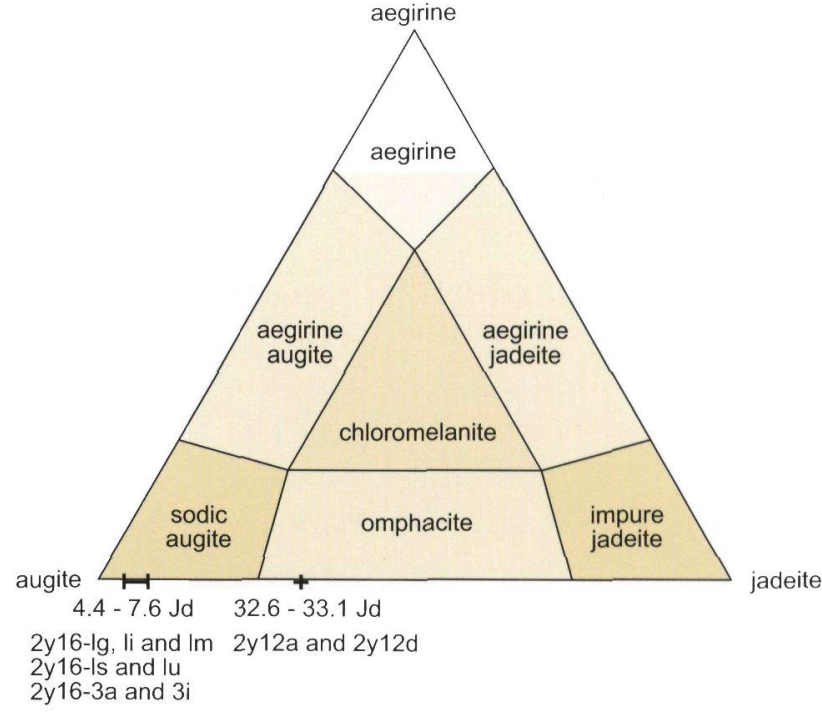

Fig. 6c. Triangular end-member diagram with clinopyroxene compositions. Type 1 (analyses numbers 2y12a and 2y12d) occurs as inclusions in garnet, location: square 2 in Fig. 4; type 2 (analyses numbers 2y16-1g, 1i, 1m, 1s, $1 u, 3 a$ and $3 i)$ within pyroxene-plagioclase symplectite. Location: square 8 in Fig. 4.

Fig. 6b. Backscattered electron micrograph showing clinopyroxene (type 2) and plagioclase (type 2) within pyroxene-plagioclase symplectite after omphacite. Analyses numbers $2 y 16-1 f, 1 \mathrm{~g}, 1 \mathrm{i}$, and $1 \mathrm{~m}$ from intermediary symplectitic area; analyses numbers $2 y 16-1 s, 1 u$ and 1v from coarse symplectitic area; analyses numbers $2 y 16-3 a, 3 h$ and $3 i$ from fine symplectitic area. Location: square 8 in Fig. 4.

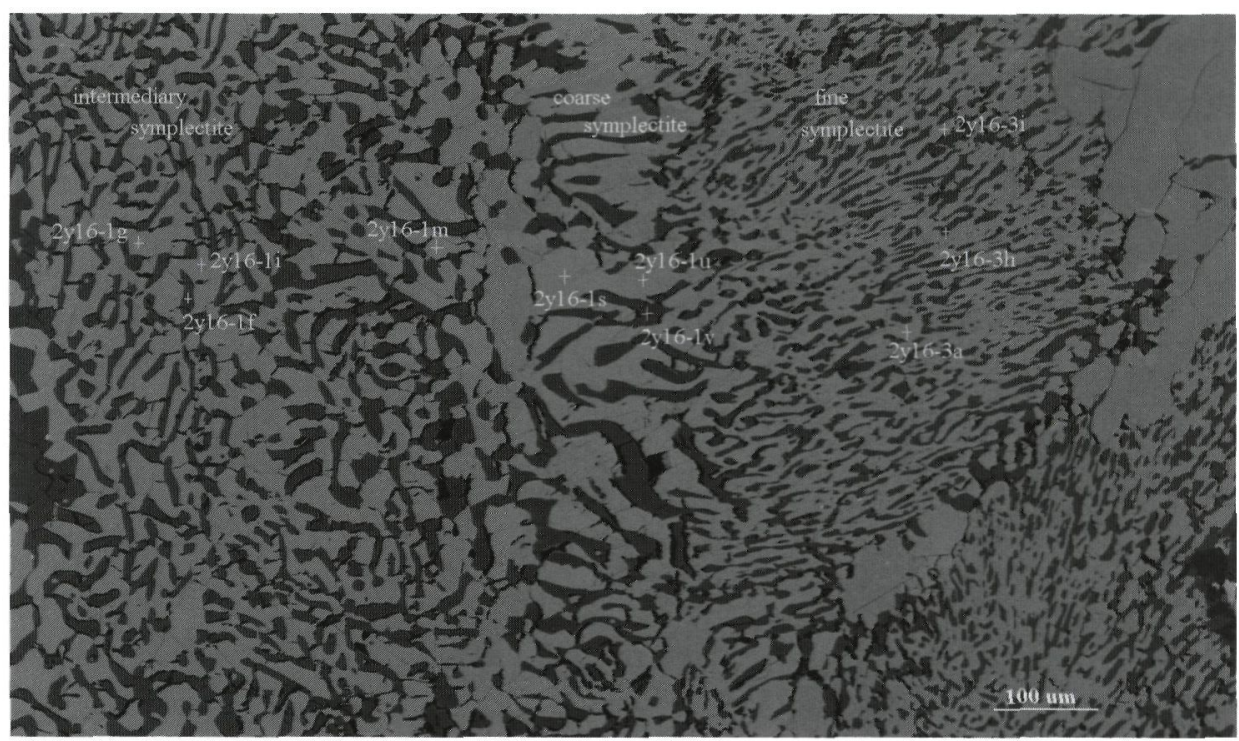

garnet is illustrated in Fig. 8a. From this figure it can be seen that the light grey primary amphibole inclusions are surrounded by secondary amphibole-plagioclase coronas that were formed during the retrograde amphibolite facies metamorphic overprint. At the core of this amphibole it is a $\mathrm{Mg}-\mathrm{Fe}-\mathrm{Mn}-\mathrm{Li}$ amphibole corresponding to cummingtonite, analysis number $2 \mathrm{y} 13 \mathrm{c} 1$ (Fig. 8c), between the core and the rim it is a calcic amphibole: magnesio-hornblende, analysis number 2y13c3 (Fig. 8d). At the rim it is also a calcic amphibole: edenite, analysis number $2 \mathrm{y} 13 \mathrm{c} 4$ (Fig. 8e). The optical colour varies from a very pale green core via a green centre to a bluish green rim.

- Type 2 amphibole is present as matrix grains. The optical colour is brownish green. It is a calcic amphibole correspon- ding to edenite. Adjacent to matrix quartz crystals, the silica content of the amphibole increases but its composition remains that of edenite.

- Type 3 amphibole is present within kelyphitic rims around garnet (together with plagioclase, Fig. 8b) but forms also part of the diopside-plagioclase symplectite after omphacite. Its optical colour is bluish green. It may form a rim around type 1 amphiboles and is therefore considered to be younger. Type 3 amphibole is calcic amphibole with different compositions: magnesio-hastingsite, analyses numbers $2 \mathrm{y} 13 \mathrm{e} 5$ and 2y13e6 (Fig. 8e) and edenite, analysis number 2y13e8 (Fig. 8e).

Type 4 amphibole is present as a rim of amphiboles around a big isolated plagioclase aggregate (Fig. 9a). The optical 
Table 3. Representative EMP analyses and calculated structural formulae of orthopyroxene around quartz included in garnet, based on 6 oxygen. $\mathrm{Fe}^{3+}$ is calculated in accordance with Schumacher (1997). Calculated is also the percentage enstatite and ferro-silite in orthopyroxene. Location: square 7 in Fig. 4.

\begin{tabular}{lccc}
\hline \multicolumn{1}{c}{ Analysis number } & $\mathrm{T} 8-16 \mathrm{a} \mathbf{n a}$ & $\mathrm{T} 8-16 \mathrm{a} \mathbf{n b}$ & T8-16a1nc1 \\
\hline $\mathrm{SiO}_{2}$ & 53.126 & 53.556 & 53.349 \\
$\mathrm{TiO}_{2}$ & 0.149 & 0.008 & 0.000 \\
$\mathrm{Al}_{2} \mathrm{O}_{3}$ & 0.881 & 0.954 & 0.901 \\
$\mathrm{Cr}_{2} \mathrm{O}_{3}$ & 0.076 & 0.000 & 0.056 \\
$\mathrm{Fe}$ & 23.302 & 23.126 & 23.651 \\
$\mathrm{MnO}$ & 0.469 & 0.436 & 0.595 \\
$\mathrm{MgO}$ & 22.202 & 22.061 & 21.793 \\
$\mathrm{CaO}$ & 0.399 & 0.342 & 0.319 \\
$\mathrm{Na}_{2} \mathrm{O}$ & 0.344 & 0.242 & 0.411 \\
$\mathrm{~K}_{20} 0$ & 0.044 & 0.000 \\
\hline Total & 0.000 & 100.70 & 101.08 \\
\hline
\end{tabular}

\begin{tabular}{lccc}
\hline Element & No. of cations & No. of cations & No. of cations \\
\hline $\mathrm{Si}$ & 1.9692 & 1.9831 & 1.9775 \\
$\mathrm{Ti}$ & 0.0041 & 0.0002 & 0.0000 \\
$\mathrm{Al}$ & 0.0385 & 0.0416 & 0.0394 \\
$\mathrm{Cr}$ & 0.0022 & 0.0000 & 0.0016 \\
$\mathrm{Fe}$ & 0.7223 & 0.7161 & 0.7331 \\
$\mathrm{Mn}$ & 0.0147 & 0.0137 & 0.0187 \\
$\mathrm{Mg}$ & 1.2269 & 1.2178 & 1.2042 \\
$\mathrm{Ca}$ & 0.0159 & 0.0136 & 0.0127 \\
$\mathrm{Na}$ & 0.0247 & 0.0173 & 0.0295 \\
$\mathrm{~K}$ & 0.0000 & 0.0021 & 0.0000 \\
\hline Total & 4.0186 & 4.0055 & 4.0168 \\
\hline & & & \\
$\mathrm{Fe}^{3+}$ & 0.055 & 0.015 & 0.049 \\
$\mathrm{Fe}^{2+}$ & 0.664 & 0.700 & 0.681 \\
& & & \\
\% enstatite & 64.3 & 63.0 & 63.1 \\
\% ferrosilite & 35.7 & 37.0 & 36.91 \\
\hline
\end{tabular}

colour is pale bluish green. It is a calcic amphibole corresponding to actinolite, analyses numbers $2 \mathrm{y} 17-11 \mathrm{a} 5$ and 2y17-12a1 (Fig. 8d).

\section{Plagioclase}

Representative EMP plagioclase analyses and a compositional plot are given in Table 5 and Fig. 9b. Three plagioclase-types were recognised.

- Type 1 occurs within the kelyphitic rim around garnet (together with amphibole, Fig. 8b). The Ca-content of this plagioclase increases towards garnet. Close to garnet it is bytownite, analysis number 2y13e4 (Fig 9b); halfway the kelyphite the Na-content increases and the plagioclase

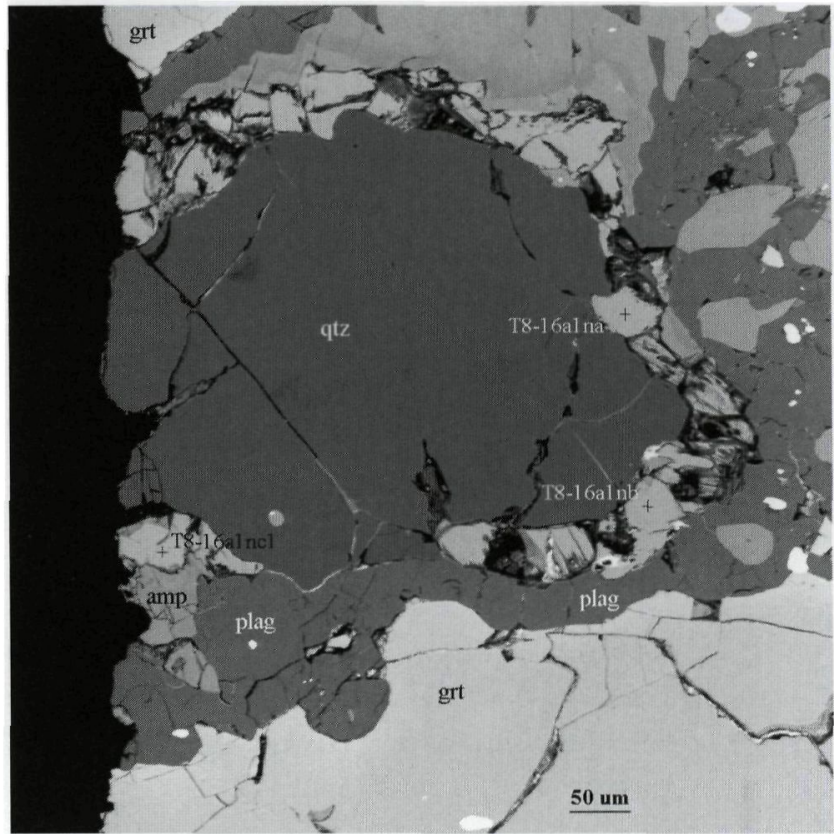

Fig. 7. Backscattered electron micrograph of orthopyroxene-plagioclase corona around a quartz grain included in garnet. Analyses numbers T8-16a1na, T8-16a1nb and T8-16a1nc1, location: square 7 in Fig. 4.

becomes labradorite, analysis number 2y13e2 (Fig. 9b); at the rim of the kelyphite the plagioclase is an andesine, analysis number 2y13e1 (Fig. 9b).

- Type 2 plagioclase occurs in the symplectite after omphacite (Fig. 6b). It is an andesine, analyses numbers $2 \mathrm{y} 16-1 \mathrm{f},-1 \mathrm{v}$ and $-3 \mathrm{~h}$ (Fig. 9b).

- Type 3 plagioclase is found within isolated aggregates spread throughout the symplectite matrix (Fig. 9a). In the core of the aggregate the plagioclase is bytownite, analyses numbers $2 \mathrm{y} 17-11 \mathrm{a} 2,-13 \mathrm{a} 2$ and $-13 \mathrm{a} 4$ (Fig. 9b); at the rim the plagioclase is andesine, analyses numbers $2 \mathrm{y} 17-11 \mathrm{a} 3$, $11 \mathrm{a} 4$ and $-13 \mathrm{a} 5$ (Fig. 9b). The primary HP origin of the aggregate is unknown (but might be zoisite).

\section{Calculated metamorphic conditions}

The estimated (minimum pressure) metamorphic conditions for the formation of the erratic (retro) eclogite block is $P \geqslant 16,2$ $\pm 1 \mathrm{~kb}$ and $\mathrm{T}=756 \pm 50^{\circ} \mathrm{C}$. These PT conditions are calculated in the following way (Fig. 10):

1. the Jd $=33,1 \%$ isopleth of omphacite is used as a (minimum) pressure indicator (Gasparik and Lindsley 1980). This isopleth line is intersected with

2. the line defined by the results of the two pyroxene thermometer of Brey and Köhler (1990, $\mathrm{T}_{\mathrm{BK}}$ in Fig. 10) calculated for $10 \mathrm{~kb}\left(742^{\circ} \mathrm{C}\right)$ and $18 \mathrm{~kb}\left(\mathrm{~T}=759^{\circ} \mathrm{C}\right)$. The EMP mineralchemical data, used to calculate $\mathrm{T}_{\mathrm{BK}}$, was obtained from lower pressure mineral assemblages but could safely be extrapolated to HP conditions as all Scandinavian eclogites reveal nearly isothermal decompression paths. 
Table 4. Representative EMP analyes and calculated structural formulae of amphiboles. Type 1, location: square 2 and 3 in Fig. 4; type 3, location: 3 in Fig. 4 and type 4 location: 9 in Fig. 4. All analyses based on 23 oxygen.

\begin{tabular}{|c|c|c|c|c|c|c|c|c|c|c|}
\hline Type & 1 & 1 & 1 & 1 & 1 & 3 & 3 & 3 & 4 & 4 \\
\hline Analysis & $2 \mathrm{y} 12 \mathrm{~b}$ & $2 \mathrm{y} 12 \mathrm{f}$ & $2 y 13 c 1$ & $2 \mathrm{y} 13 \mathrm{c} 3$ & $2 y 13 c 4$ & $2 \mathrm{y} 13 \mathrm{e} 5$ & $2 \mathrm{y} 13 \mathrm{e} 6$ & $2 y 13 e 8$ & $2 \mathrm{y} 17-$ & $2 y 17-$ \\
\hline number & & & & & & & & & $11 \mathrm{a} 5$ & $12 \mathrm{a} 1$ \\
\hline $\mathrm{SiO}_{2}$ & 51.042 & 43.200 & 54.457 & 52.514 & 45.224 & 43.503 & 42.290 & 47.113 & 52.724 & 53.315 \\
\hline $\mathrm{TiO}_{2}$ & 0.270 & 0.785 & 0.000 & 0.000 & 0.317 & 0.187 & 0.471 & 0.543 & 0.000 & 0.000 \\
\hline $\mathrm{Al}_{2} \mathrm{O}_{3}$ & 5.903 & 14.265 & 0.286 & 5.309 & 11.846 & 14.088 & 14.946 & 17.896 & 4.312 & 4.095 \\
\hline $\mathrm{Cr}_{2} \mathrm{O}_{3}$ & 0.031 & 0.000 & 0.000 & 0.000 & 0.000 & 0.000 & 0.154 & 0.226 & 0.000 & 0.212 \\
\hline $\mathrm{FeO}$ & 11.764 & 11.922 & 20.000 & 10.431 & 12.553 & 12.802 & 14.240 & 10.317 & 11.452 & 10.885 \\
\hline MnO & 0.054 & 0.000 & 0.240 & 0.163 & 0.000 & 0.163 & 0.008 & 0.182 & 0.185 & 0.283 \\
\hline $\mathrm{MgO}$ & 16.952 & 12.380 & 20.825 & 17.474 & 13.110 & 11.838 & 11.055 & 7.446 & 16.725 & 16.707 \\
\hline $\mathrm{CaO}$ & 9.900 & 11.884 & 0.844 & 11.256 & 11.027 & 11.845 & 11.611 & 10.773 & 11.493 & 11.509 \\
\hline $\mathrm{Na}_{2} \mathrm{O}$ & 1.129 & 2.242 & 0.373 & 1.106 & 2.118 & 2.337 & 2.291 & 3.432 & 0.915 & 0.818 \\
\hline $\mathrm{K}_{2} \mathrm{O}$ & 0.046 & 0.187 & 0.000 & 0.000 & 0.085 & 0.276 & 0.137 & 0.268 & 0.166 & 0.060 \\
\hline Total & 97.091 & 96.866 & 97.025 & 98.253 & 96.310 & 97.039 & 97.203 & 98.196 & 97.973 & 97.884 \\
\hline
\end{tabular}

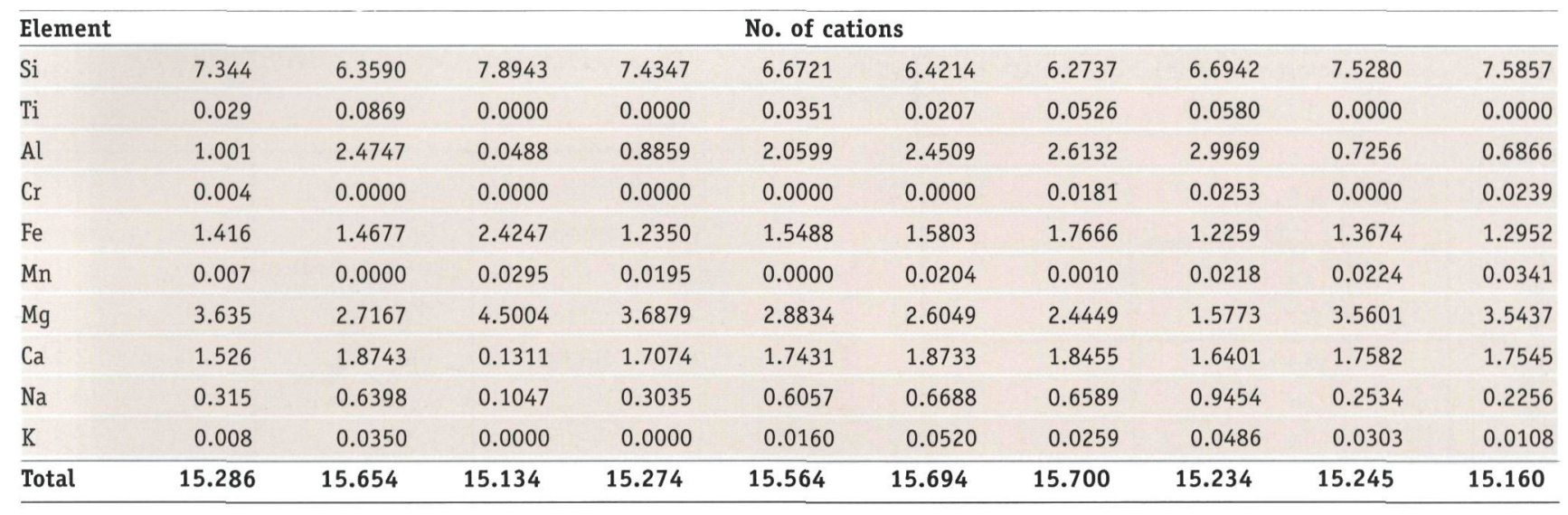

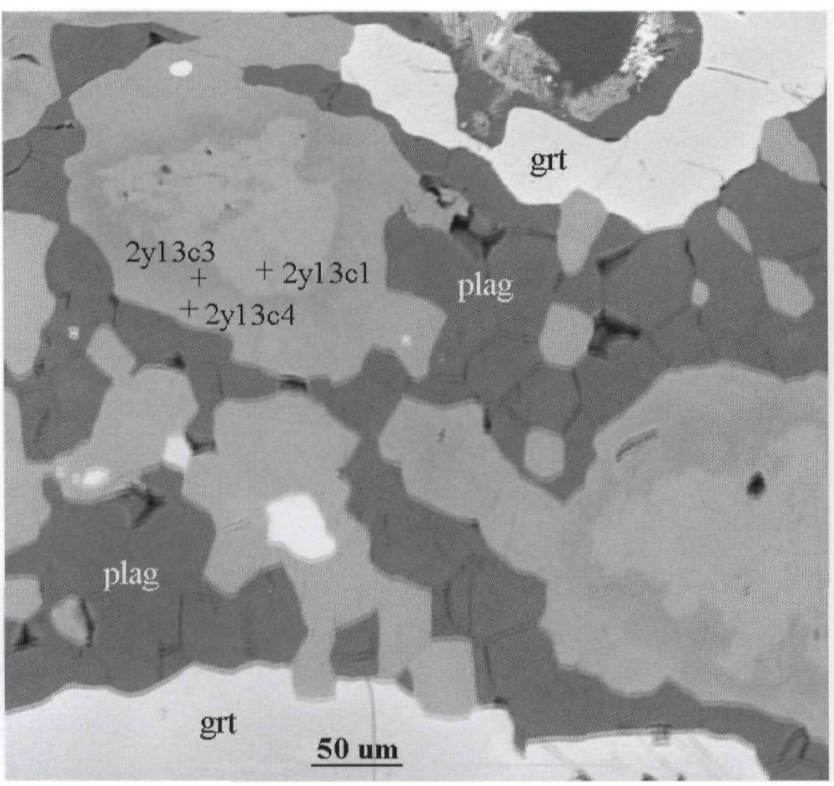

Fig. 8a. Backscattered electron micrograph of type 1 calcic amphibole included in garnet, the amphibole is zoned (light and dark grey) corresponding to cummingtonite (analysis number 2y13c1), magnesiohornblende (analysis number 2y13c3) and edenite (analysis number 2y13c4). Location: square 3 in Fig. 4.

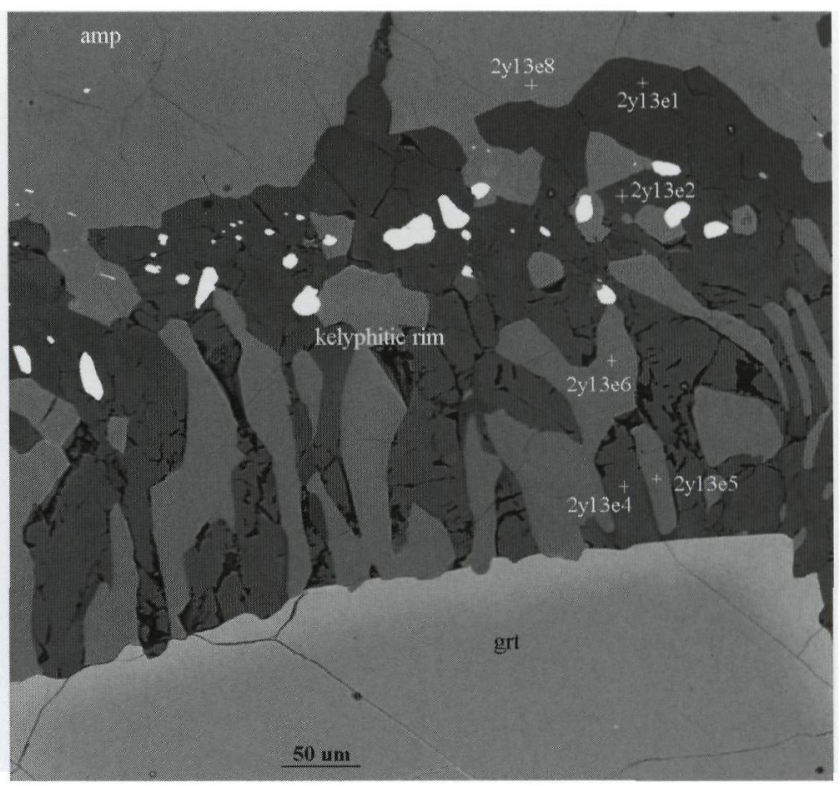

Fig. 8b. Backscattered electron micrograph of type 3 calcic amphibole in a kelyphitic rim around garnet, corresponding to magnesio-hastingsite (analyses numbers 2y13e5, e6) and edenite (analysis number 2y13e8). Also you can see type 1 plagioclase analysis number $2 y 13 e 1$ (andesine), analysis number 2y13e2 (labradorite) and 2y13e4 (bytownite). Location: square 3 in Fig. 4. 
Mg- Fe- Mn- Li amphiboles

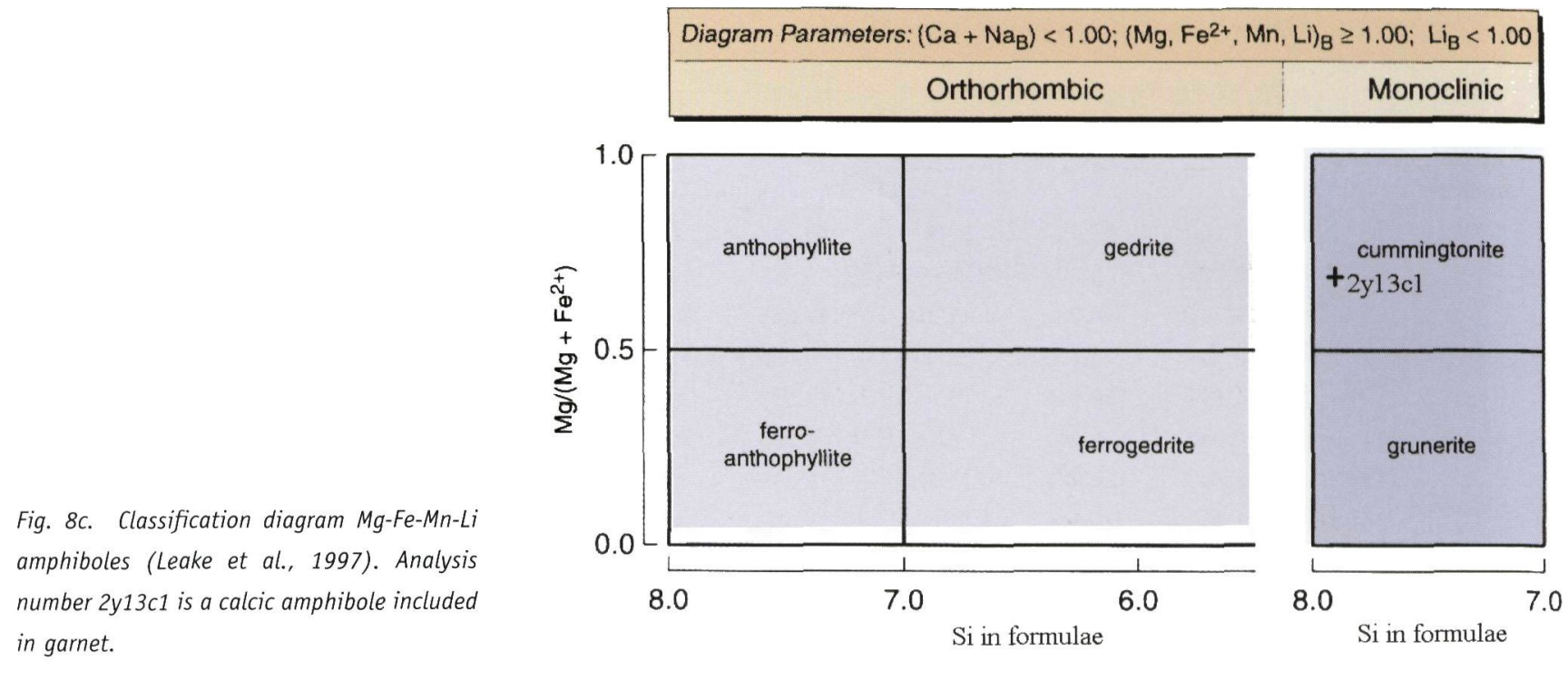

Calcic amphiboles
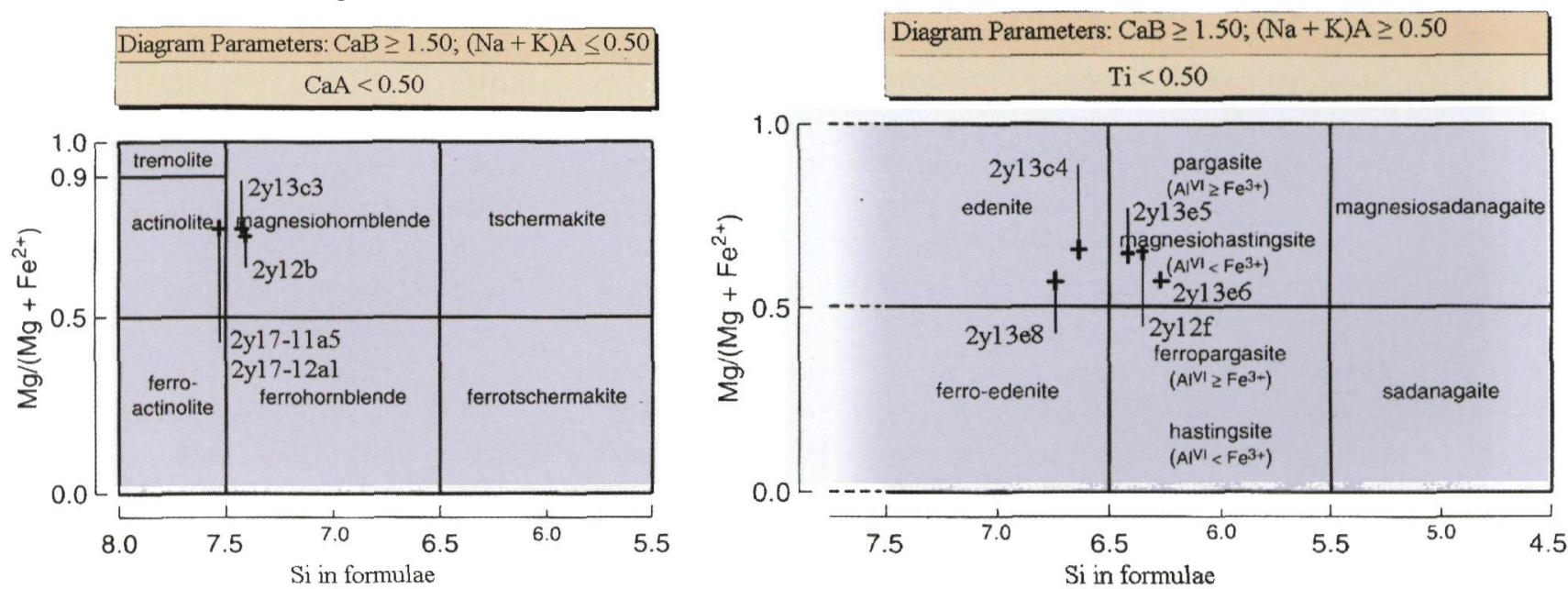

Fig. 8d. Classification diagram of calcic amphiboles $(\mathrm{Na}+\mathrm{K})_{A}$ $\leqslant 0,50$ (Leake et al., 1997). Analysis number $2 y 13 c 3$ is a zoned calcic amphibole included in garnet, $2 \mathrm{y} 12 \mathrm{~b}$ is a calcic amphibole also included in garnet and 2y17-11a5 and $12 a 1$ are calcic

Fig. 8e. Classification diagram of calcic amphiboles $(\mathrm{Na}+K)_{A} \geqslant 0,50$ (Leake et al., 1997). Analyses numbers $2 y 13 e 5, e 6$ and e8 are calcic amphiboles from kelyphitic rim around garnet, analysis number $2 y 13 c 4$ is a zoned calcic amphibole included in garnet and $2 \mathrm{y} 12 \mathrm{f}$ is also a calcic amphibole included in garnet.

amphiboles around an isolated plagioclase aggregate.

This extrapolation method was preferred above the classical thermometers of Råheim and Green (1975), Ellis and Green (1979) and Krogh (1988) which gave unrealistically high temperatures $\left(\mathrm{T}=1062{ }^{\circ} \mathrm{C}\right.$ at $\left.\mathrm{P} \geqslant 20.1 \mathrm{~kb}\right)$. We interpreted the latter as being due to $\mathrm{Fe}-\mathrm{Mg}$ exchange in omphacite during decompression.

\section{Discussion and conclusion}

The calculated PT conditions, the percentage pyrope in garnet and the percentage jadeite in omphacite in the Haren erratic block were compared with those reported in the literature for the three (U)HPM terranes in Sweden (Table 6).
In addition the primary mineral assemblage of the eclogites is:

- Northern Jämtland, Central Belt: omphacite + garnet + quartz + rutile + zircon + apatite + zoisite (Van Roermund 1985).

- Northern Jämtland, Eastern Belt: omphacite+ garnet+ quartz+ rutile+ zircon+ apatite+ phengite (Van Roermund 1985).

- Norrbotten, Vaimok Lens: garnet + omphacite + rutile + quartz \pm phengite (Santallier 1988).

- Norrbotten, Tsäkkok Lens: garnet + omphacite + quartz + rutile + phengite + zoisite (Mørk, Kullerud and Stabel, 1988).

- Halland, the eclogite is kyanite bearing and contains sapphirine-plagioclase assemblage in a corona around around kyanite, no phengite (Möller 1998, 1999). 
Table 5. Representative EMP analyes and calculated structural formulae of plagioclase type1 in a kelyphitic rim around garnet, location: square 3 in Fig.4; type 2 in a pyroxene-plagioclase symplectite, location: square 8 in Fig. 4 and type 3 in a big isolated plagioclase aggregate, location: square 9 in Fig. 4. All analyses based on 8 oxygen.

\begin{tabular}{|c|c|c|c|c|c|c|c|c|c|c|c|c|}
\hline Type & 1 & 1 & 1 & 2 & 2 & 2 & 3 & 3 & 3 & 3 & 3 & 3 \\
\hline $\begin{array}{l}\text { Analysis } \\
\text { number }\end{array}$ & $2 \mathrm{y} 13 \mathrm{e} 1$ & $2 \mathrm{y} 13 \mathrm{e} 2$ & $2 y 13 e 4$ & $2 \mathrm{y} 16-1 \mathrm{f}$ & $2 \mathrm{y} 16-1 \mathrm{v}$ & $2 \mathrm{y} 16-3 \mathrm{~h}$ & $\begin{array}{l}2 \mathrm{y} 17- \\
11 \mathrm{a} 2\end{array}$ & $\begin{array}{l}2 \mathrm{y} 17- \\
11 \mathrm{a} 3\end{array}$ & $\begin{array}{l}2 \mathrm{y} 17- \\
11 \mathrm{a} 4\end{array}$ & $\begin{array}{l}2 \mathrm{y} 17- \\
13 \mathrm{a} 2\end{array}$ & $\begin{array}{l}2 \mathrm{y} 17- \\
13 \mathrm{a} 4\end{array}$ & $\begin{array}{l}2 \mathrm{y} 17- \\
13 \mathrm{a} 5\end{array}$ \\
\hline $\mathrm{SiO}_{2}$ & 55.926 & 51.262 & 47.505 & 59.975 & 59.866 & 59.300 & 49.189 & 56.112 & 57.700 & 48.231 & 47.464 & 58.371 \\
\hline $\mathrm{TiO}_{2}$ & 0.072 & 0.000 & 0.104 & 0.000 & 0.043 & 0.089 & 0.036 & 0.000 & 0.005 & 0.000 & 0.133 & 0.006 \\
\hline $\mathrm{Al}_{2} \mathrm{O}_{3}$ & 28.122 & 30.211 & 32.639 & 26.177 & 26.085 & 25.792 & 33.160 & 28.651 & 27.786 & 33.566 & 33.779 & 27.106 \\
\hline $\mathrm{Cr}_{2} \mathrm{O}_{3}$ & 0.003 & 0.085 & 0.262 & 0.000 & 0.058 & 0.053 & 0.124 & 0.041 & 0.000 & 0.000 & 0.000 & 0.000 \\
\hline $\mathrm{Fe} 0$ & 0.194 & 0.429 & 0.589 & 0.363 & 0.288 & 0.245 & 0.240 & 0.127 & 0.466 & 0.280 & 0.315 & 0.098 \\
\hline MnO & 0.053 & 0.191 & 0.119 & 0.000 & 0.000 & 0.000 & 0.056 & 0.000 & 0.065 & 0.034 & 0.063 & 0.000 \\
\hline MgO & 0.000 & 0.000 & 0.000 & 0.000 & 0.000 & 0.000 & 0.000 & 0.000 & 0.000 & 0.000 & 0.000 & 0.000 \\
\hline $\mathrm{CaO}$ & 9.381 & 12.734 & 15.983 & 7.365 & 7.480 & 7.962 & 15.225 & 10.355 & 8.903 & 16.353 & 16.953 & 8.484 \\
\hline $\mathrm{Na}_{2} \mathrm{O}$ & 6.489 & 4.380 & 2.785 & 7.718 & 7.829 & 7.508 & 2.854 & 5.974 & 6.624 & 2.378 & 2.046 & 7.230 \\
\hline $\mathrm{K}_{2} \mathrm{O}$ & 0.000 & 0.009 & 0.000 & 0.034 & 0.016 & 0.000 & 0.050 & 0.102 & 0.074 & 0.001 & 0.000 & 0.072 \\
\hline Total & 100.24 & 99.30 & 99.99 & 101.63 & 101.67 & 100.95 & 100.93 & 101.36 & 101.63 & 100.84 & 100.75 & 101.37 \\
\hline
\end{tabular}

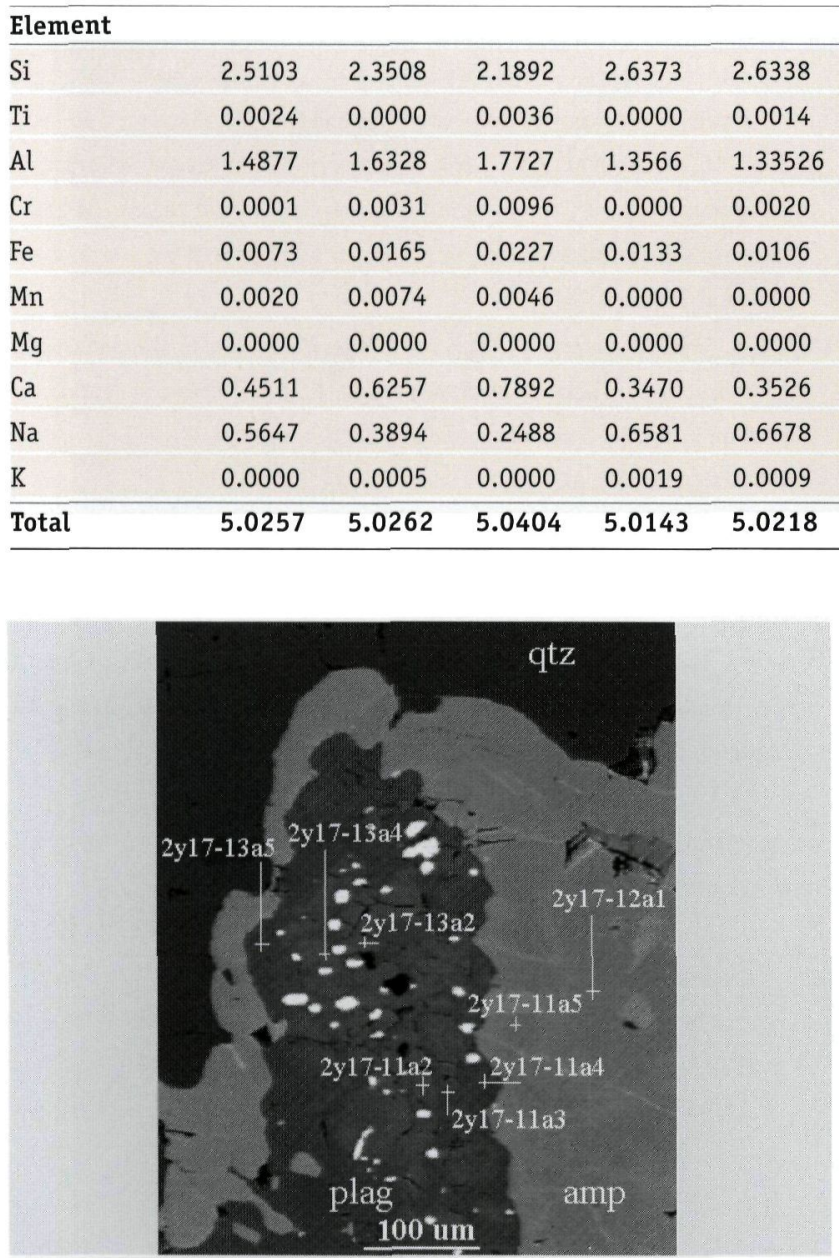

Fig. 9a. Backscattered electron micrograph illustrating a big isolated plagioclase aggregate with a rim of amphiboles. Analyses numbers $2 y 17-$ $11 a 5$ and $12 a 1$ are actinolites (Fig. 8d). The plagioclase aggregate in the core is a bytownite (analyes numbers 2y17-11a2, $13 a 2$ and 13a4, Fig. 96 ) and in the rim an andesine (analyses numbers 2y17-11a3, 11a4 and 13a5, Fig. 9b). Location: square 9 in Fig. 4.

\section{No. of cations}

\begin{tabular}{lllllll}
\hline 2.6296 & 2.2288 & 2.4941 & 2.5493 & 2.1936 & 2.1638 & 2.5814 \\
0.0030 & 0.0012 & 0.0000 & 0.0002 & 0.0000 & 0.0046 & 0.0002 \\
1.3479 & 1.7708 & 1.5009 & 1.4469 & 1.7993 & 1.8149 & 1.4128 \\
0.0019 & 0.0044 & 0.0014 & 0.0000 & 0.0000 & 0.0000 & 0.0000 \\
0.0091 & 0.0091 & 0.0047 & 0.0172 & 0.0107 & 0.0120 & 0.0036 \\
0.0000 & 0.0021 & 0.0000 & 0.0024 & 0.0013 & 0.0024 & 0.0000 \\
0.0000 & 0.0000 & 0.0000 & 0.0000 & 0.0000 & 0.0000 & 0.0000 \\
0.3783 & 0.7391 & 0.4931 & 0.4214 & 0.7969 & 0.8281 & 0.4020 \\
0.6455 & 0.2507 & 0.5149 & 0.5674 & 0.2097 & 0.1808 & 0.6199 \\
0.0000 & 0.0029 & 0.0058 & 0.0042 & 0.0001 & 0.0000 & 0.0041 \\
\hline 5.0153 & 5.0092 & 5.0150 & 5.0091 & 5.0116 & 5.0066 & 5.0240
\end{tabular}

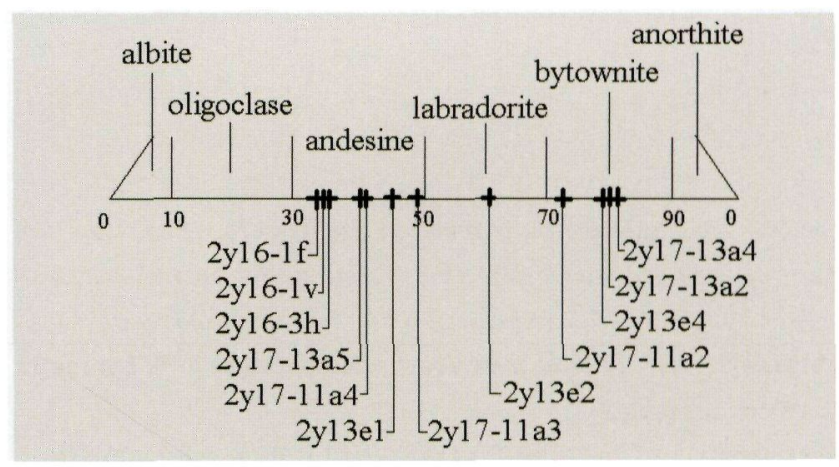

Fig. 9b. Compositional plot of analysed plagioclases. Analyses numbers 2y16-1f, $1 \mathrm{v}$ and $3 \mathrm{~h}$ from a pyroxene-plagioclase symplectite (Fig.6b); $2 y 17-13 a 5,11 a 4,11 a 3,11 a 2,13 a 2$ and $13 a 4$ (Fig. 9a) are from the big isolated plagioclase aggregate; $2 y 13 e 1, e 2$ and e4 (Fig. $8 b$ ) are from a kelyphitic rim around garnet. 


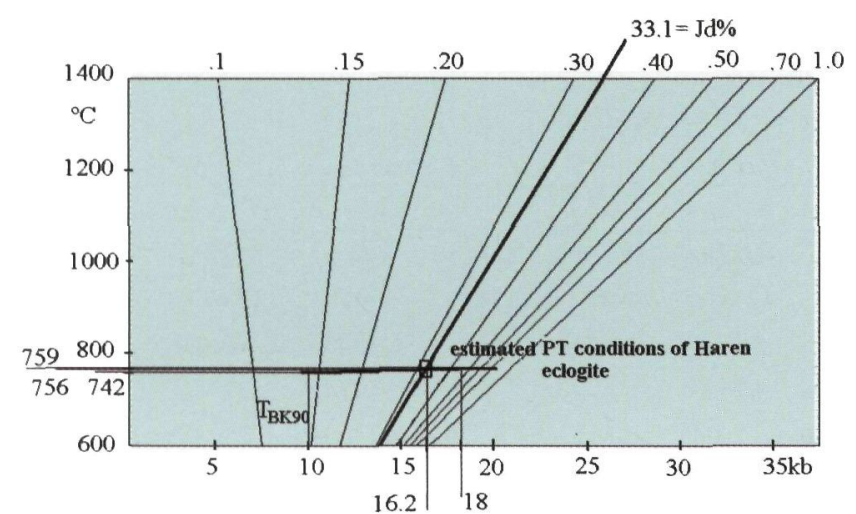

Fig. 10. PT diagram showing the estimated PT conditions calculated using $J d=33.1 \%$ isopleth of omphacite (analysis number $2 y 12 d$, Gasparik and Lindsley, 1980) intersected with the nearly isothermal results of the two pyroxene thermometer $\left(T_{B K 90}\right)$ of Brey and Köhler (1990) at 10 and $18 \mathrm{~kb}$.

- The mineral assemblage of the erratic HP rock from Haren (Gr.) is omphacite + garnet + quartz + rutile + zircon + apatite + zoisite.

Based on the information given above we conclude that the (U)HPM terrane in Northern Jämtland, Sweden, more precisely the Ertsekey (U)HP tectonic lens of the Central Belt of the Seve Nappe Complex, represents the most likely origin of the erratic block found in Haren, Groningen, the Netherlands. This conclusion is fully consistent with results of other indicator pebble counts from the Haren area (Zandstra 1988), which indicates that most of the rocks, found in Haren, originate from the so called Eastern Baltic area.

Based on this study we predict that the age of the Haren erratic (retro) eclogite block will be $455 \mathrm{Ma}$.

\section{Acknowledgements}

We like to thank Mr. G. Dijk from Groningen, the Netherlands, for allowing us to investigate the (retro) eclogite found in Haren (Gr.). Unfortunately, he could not see the completion of this study. Furthermore, J.L. likes to thank everyone who supported him during this study, more particular Dr. C. Maijer without whom I would never be able to 'read' a thin section; Prof. Dr. B. de Jong, University of Utrecht, the Netherlands for supporting the project financially and Mr. 0. Stiekema, IVA, Utrecht, for learning him how to make thin sections.

\section{References}

Albrecht, L.G., 2000. Structural evolution of eclogite-bearing nappes. Evidence from the Seve Nappe Complex, Swedish Caledonides. In: Early structural and metamorphic evolution of the Scandinavian Caledonides: a study of the eclogite bearing Seve Nappe Complex at the Arctic Circle, Sweden. PhD Thesis, Lund University, Ch. 6: 1-15.

Andreasson, P.G., Gee, D.G. \& Sukotji, S., 1985. Seve eclogites in the Norrbotten Caledonides, Sweden. In: D.G. Gee \& B.A. Sturt (eds): The Caledonide Orogen - Scandinavia and Related Areas. John Wiley and Sons Ltd, Chichester: 887-901.

Berglund, J. \& Connelly, J.N., 1994. Sveconorwegian structural evolution in the eastern segment of the southwest Swedish Gneiss Region. Abstract. Precambrium Crustal Evolution in the North Atlantic Regions, Nottingham, UK. Terra Abstracts, 2 (6): 2.

Bingen, B., Skår, Ø., Marker, M., Sigmond, E.M.0., Nordgulen, Ø., Ragnhildstveit, J., Mansveld, J., Tucker, R.D. \& Liégeois, J.-P., 2005. Timing of continental building in the Sveconorwegian orogen, SW Scandinavia. Norwegian Journal of Geology, Vol. 85: 87-116.

Brey, G.P. \& Köhler, T., 1990. Geothermobarometry in four phase Iherzolites. Part II: New thermobarometers and practical assessment of existing thermobarometers. Journal of Petrology 31: 1353-1378.

Brueckner, H.K. \& Van Roermund, H.L.M., 2004. Dunk tectonics: A multiple subduction/eduction model for the evolution of the Scandinavian Caledonides. Tectonics, 23-1, TC 2004: 1-20.

Table 6. This table illustrates minimum pressure $(P)$, temperature $(T)$, percentage pyrope in garnet and percentage jadeite in omphacite from the Northern Jämtland, Norrbotten, Halland metamorphic terranes and the Haren (retro) eclogite.

\begin{tabular}{|c|c|c|c|c|c|}
\hline Terrane & Min. pressure & Temperature & $\%$ Pyrope in garnet & $\%$ Jadeite in omphacite & Author \\
\hline \multicolumn{6}{|c|}{ Northern Jämtland } \\
\hline Central Belt & $P \geqslant 18.0 \pm 1 \mathrm{~kb}$ & $780 \pm 50^{\circ} \mathrm{C}$ & $22-35$ & $28-41$ & Van Roermund 1985 \\
\hline Eastern Belt & $P \geqslant 16.5 \pm 1 \mathrm{~kb}$ & $650 \pm 50^{\circ} \mathrm{C}$ & $8-22$ & $\approx 48$ & Van Roermund 1985, Litjens 2002 \\
\hline
\end{tabular}

Norrbotten

$\begin{array}{llllll}\text { Vaimok Lens } & P \geqslant 19.0 \pm 1 \mathrm{~kb} & 700 \pm 50^{\circ} \mathrm{C} & 18-32 & 36-46 & \text { Santallier 1988, Mørk et al. 1988 } \\ \text { Tsäkkok Lens } & P \geqslant 14.9 \pm 1.5 \mathrm{~kb} & 610 \pm 90^{\circ} \mathrm{C} & \text { up to } 42 & 33-44 & \text { Stephens and Van Roermund 1984 }\end{array}$

Halland $\quad \mathrm{P} \geqslant 10.8 \pm 1.2 \mathrm{~kb} \quad 750 \pm 45^{\circ} \mathrm{C}$ not known not known 1998

Haren $\quad P \geqslant 16.2 \pm 1 \mathrm{~kb} \quad 756 \pm 50^{\circ} \mathrm{C} \quad 21-35 \quad 32.6-33.1$


Brueckner, H.K. \& Van Roermund, H.L.M., 2007. Concurrent HP Metamorphism on both Margins of Iapetus: Ordovician ages for Eclogites and Garnet Pyroxenites from the Seve Nappe Complex, Swedish Caledonides. Journal of the Geological Society (London) 2007, 117-128.

Carswell, D.A. (ed.), 1990. Eclogite Facies Rocks, Blackie and Son Ltd. (Glasgow): $1-396$.

Coleman, R.G., Lee, D.E., Beatty, L.B. \& Brannock, W.W., 1965. Eclogites and eclogites: Their differences and similarities. Geological Society of America Bulletin, 76: 483-504.

Ellis, D.J. \& Green, D.H., 1979. An experimental study of the effect of Ca upon garnet-clinopyroxene Fe-Mg exchange equilibria. Contributions to Mineralogy and Petrology, 71, 13-22.

Essex, R.M., Gromet, L.P., Andreasson, P.G. \& Albrecht, L., 1997. Early Ordovician $\mathrm{U}-\mathrm{Pb}$ metamorphic ages of the eclogite-bearing Seve Nappes, Northern Scandinavian Caledonides. Journal of Metamorphic Geology, 15: 665-676.

Gasparik, T. \& Lindsley, D.H., 1980. Phase equilibria at high pressure of pyroxenes containing monovalent and trivalent ions. Reviews in Mineralogy, Mineralogical Society of America, 7: 309-339.

Huisman, H., 1982. Een zwerfsteen van kelyphietische hoornblende-eklogiet. Grondboor en Hamer, 5: 130-132.

Kaulina, T. \& Apanasevich, E., 2005. Late Archean Eclogites of the Kola Peninsula (NE Baltic Shield): U-Pb and Sm-Nd Data. Mitteilungen der Österreichischen Mineralogischen Gesellschaft. Band 150: p 64.

Krogh, E.J., 1988. The garnet-clinopyroxene Fe-Mg geothermometer - A reinterpretation of existing experimental data. Contributions to Mineralogy and Petrology, 99: 44-48.

Kullerud, K., Stephens, M. B. \& Zachrisson, E., 1990. Pillow lavas as protoliths for eclogites: evidence from a late Precambrian-Cambrian continental margin, Seve Nappes, Scandinavian Caledonides. Contributions to Mineralogy and Petrology, 105: 1-10.

Leake, B.E. \& Woolley, A.R., 1997. Nomenclature of amphiboles. Report of the Subcommittee on Amphiboles of the International Mineralogical Association Commission on New Minerals and Mineral Names. European Journal of Mineralogy, 9: 623-651.

Litjens, A., 2002. PT estimates of high-pressure metamorphic rocks from the Seve Nappe Complex, Jämtland, Central Scandinavian Caledonides. MSc Thesis, University of Utrecht, the Netherlands: 1-94.

Möller, C. \& Söderlund, U., 1997. Age constraints on the regional deformation within the Eastern Segment, S. Sweden: Late Sveconorwegian granite dyke intrusion and metamorphic-deformational relations. Geologiska Föreningens i Stockholm Förhandlingar, 119: 1-12.

Möller, C., 1998. Decompressed eclogites in the Sveconorwegian (Grenvillian) orogen of SW Sweden: petrology and tectonic implications. Journal of metamorphic Geology, 16: 641-656.

Möller, C., 1999. Sapphirine in SW Sweden: a record of Sveconorwegian (Grenvillian) late-orogenic tectonic exhumation. Journal of metamorphic Geology, 17, 127-141.

Mørk, M.B.E., Kullerud, K. \& Stabel, A., 1988. Sm-Nd dating of Seve eclogites, Norrbotten, Sweden - Evidence for early Caledonian (505 Ma) subduction. Contributions to Mineralogy and Petrology, 99: 344-351.

Råheim, A. \& Green, D.H., 1975. P, T paths of natural eclogites during metamorphism - A record of subduction. Lithos, 8: 317-328.
Santallier, D., 1988. Mineralogy and crystallization of the Seve eclogites in the Vuoggatjålme Area, Swedish Caledonides of Norrbotten. Geologiska Föreningens i Stockholm Förhandlingar, 110: 89-98.

Schumacher, J.C., 1997. Nomenclature of amphiboles. Report of the Subcommittee on Amphiboles of the International Mineralogical Association Commission on New Minerals and Mineral Names, Appendix 2. European Journal of Mineralogy, 9: 623-651.

Smed, P., 1994. Steine aus dem Norden. Gebrüder Borntraeger, Berlin-Stuttgart: $194 \mathrm{pp}$.

Stephens, M.B. \& Van Roermund, H.L.M., 1984. Occurrence of glaucophane and crossite in eclogites of the Seve Nappes, southern Norrbotten Caledonides, Sweden. Norsk Geologisk Tidsskrift, 64: 155-163.

Stichting Wetenschappelijke Atlas van Nederland, 1985. Atlas van Nederland, deel 13, Geologie. Staatsuitgeverij, 's-Gravenhage.

Van Roermund, H.L.M., 1985. Eclogites of the Seve Nappe, central Scandinavian Caledonides. In: D.G. Gee \& B.A. Sturt (eds): The Caledonide OrogenScandinavia and Related Areas, John Wiley and Sons Ltd (Chichester): 873-886.

Van Roermund, H.L.M., 1989. High-pressure ultramafic rocks from the Allochthonous Nappes of the Swedish Caledonides. In: R.A. Gayer (ed.): The Caledonide Geology of Scandinavia, Graham and Trotman (London): 205-219.

Van Roermund, H.L.M. \& Bakker, E., 1984. Structure and metamorphism of the Tången-Inviken area, Seve Nappes, Central Scandinavian Caledonides. Geologiska Föreningens i Stockholm Förhandlingar, 105: 301-319.

Williams, P.F. \& Zwart, H.J., 1977. A model for the development of the SeveKöli Caledonian Nappe Complex. In: Saxena, S.K. \& Bhattacharji, S. (eds): Energetics of Geological Processes, Springer Verlag, New York: 170-187.

Zandstra, J.G., 1988. Noordelijke Kristallijne Gidsgesteenten. E.J. Brill, Leiden New York - København - Köln: 469 pp.

Zandstra, J.G., 1999. Platenatlas van noordelijke kristallijne gidsgesteenten. Backhuys Publishers (Leiden): 412 pp.

Zwart, H.J., 1974. Structure and metamorphism in the Seve-Köli Nappe Complex and its implications concerning the formation of metamorphic nappes. Centre du Societé Geologique de Belgique: 129-144. 